FEDERAL RESERVE BANK OF SAN FRANCISCO

WORKING PAPER SERIES

\title{
A Quantitative Analysis of China's Structural Transformation
}

\author{
Robert Dekle \\ University of Southern California \\ Guillaume Vandenbroucke \\ University of Southern California
}

May 2006

Working Paper 2006-37

http://www.frbsf.org/publications/economics/papers/2006/wp06-37bk.pdf

The views in this paper are solely the responsibility of the authors and should not be interpreted as reflecting the views of the Federal Reserve Bank of San Francisco or the Board of Governors of the Federal Reserve System. This paper was produced under the auspices for the Center for Pacific Basin Studies within the Economic Research Department of the Federal Reserve Bank of San Francisco. 


\title{
A Quantitative Analysis of China's Structural Transformation*
}

\author{
Robert Dekle \\ Guillaume Vandenbroucke \\ University of Southern California University of Southern California
}

May 15, 2006

\begin{abstract}
Between 1978 and 2003 the Chinese economy experienced a remarkable 5.7 percent annual growth of GDP per labor. At the same time, there has been a noticeable transformation of the economy: the share of workers in agriculture decreased from over 70 percent to less than 50 percent. We distinguish three sectors: private agriculture and nonagriculture and public nonagriculture. A growth accounting exercise reveals that the main source of growth was TFP in the private nonagricultural sector. The reallocation of labor from agriculture to nonagriculture accounted for 1.9 percent out of the 5.7 percent growth in output per labor. The reallocation of labor from the public to the private sector also accounted for a significant part of growth in the 19962003 period. We calibrate a general equilibrium model where the driving forces are public investment and employment, as well as sectorial TFP derived from our growth accounting exercise. The model tracks the historical employment share of agriculture and the labor productivities of all three sectors quite well.
\end{abstract}

Keywords: China, structural transformation, growth.

JEL Classification Nos: O41, O53.

\section{Introduction}

Between 1978 and 2003, the Chinese economy experienced a real annual rate of total GDP growth of 8.4 percent, a performance that makes China the most rapidly growing economy in the world during this period. Labor productivity grew during this period at a remarkable 5.7 percent per year. At the same time, there has been a sharp transformation of the Chinese economy, as millions of workers left the agricultural sector, to join the industrial sector, reducing the share of workers in agriculture from over 70 percent of all workers in 1978, to under 50 percent in 2003. What are the driving forces of this rapid growth and structural transformation of the Chinese economy? In this paper, we develop

*Xiaowen Zhang provided exceptional research assistance. Conversations with Carsten Holtz, Yong Kim, Sam Kortum, Justin Lin, Tom Rawski, John Strauss, and Guofu Tan are deeply appreciated. 
a quantitative, general equilibrium growth model to try to capture China's recent growth and structural transformation. We use this model to project the likely path of China's future growth, and the role the transfer of labor from agriculture to nonagriculture will play in this growth.

Our model has three sectors, the agricultural sector, the nonagricultural private sector, and the nonagricultural public (government) sector. The agricultural and the nonagricultural private sectors are profit maximizing; but we leave the objective of the Chinese public sector unspecified; the public sector simply extracts labor and capital from the rest of the economy. China is nominally still a socialist economy. At the beginning of our period, 1978, the public sector produced nearly all of nonagricultural output. Even in 1990, public sector output was over 90 percent of nonagricultural output. Thus, for China, it is important to model the public sector explicitly.

Technological progress is exogenous in all three sectors, but is highest in the nonagricultural private sector. We show in the analysis of our model that the expansion of the nonagricultural public sector-which occurred in China from the late-1970s to the mid1990s-will draw labor out of agriculture. We also show that the more rapid technological progress in the private nonagriculture sector will draw labor out of agriculture. A rise in private nonagricultural productivity will tend to lower the relative price of nonagricultural goods, raising the demand for labor in private nonagriculture, at the expense of labor in agriculture. Using plausible parameter values, we simulate our model and find that the model tracks the historical employment share of agriculture, and the labor productivities of all three sector remarkably well. Thus, the two main driving forces for China's structural transformation- or the decline in the agricultural share of employment-are the expansion of the nonagricultural public sector; and especially since the mid-1990s, the rapid technological progress in the private nonagricultural sector.

Although many descriptive accounts of China's structural transformation exist, to the best of our knowledge, our paper is the first quantitative growth model of the Chinese economy from 1978 to 2003 . The only other related paper that we know of that analytically tries to explain China's structural transformation is Brandt, Hsieh, and Zhu (2005). As in this paper, Brandt, Hsieh, and Zhu attribute the structural transformation of China mainly to technological progress, although the details of their model differ significantly from ours. Brandt, Hsieh, and Zhu do not examine the role of the Chinese public sector in the country's structural transformation, nor do they simulate their model to see how well their model tracks China's historical experience.

Another contribution of this paper is the development of a consistent set of Chinese accounts for the agricultural sector, and for the public and private nonagricultural sectors, that enables us to compare our growth model with the data. In a well-known paper, Young (2003) has showed by adjusting the Chinese national accounts, that labor productivity 
in the national accounts is significantly overestimated for the nonagricultural sector. We apply Young's methodology separately to the agricultural sector, and to the nonagricultural sector disaggregated into the public and private spheres.

We perform a growth accounting exercise using our adjusted national accounts data. Among the interesting findings is that between 1978 and 2003, annual total factor productivity growth in the public sector was essentially zero, while that in the private sector was over 7 percent. Between 1978 and 2003, out of total labor productivity growth of 5.7 percent, the contribution of structural transformation, or the reallocation of labor from agriculture to nonagriculture was a respectable 1.9 percent. However, the contribution of this labor reallocation declined over time, and was only 0.2 percent out of 5.8 percent between 1996 and 2003. During this latter period, the contribution of private sector productivity growth surged to 2.7 percent, and the contribution of the reallocation of labor from the public to the private sphere rose to 1.0 percent. Thus, presently, and probably into the future, the drivers of Chinese total GDP and labor productivity growth will be the shrinkage of the inefficient public (government) sector; and particularly, technological progress in the private sector.

This paper is organized as follows. In the next Section, we describe the Chinese data, and how we adjust the data. To obtain sectorial total factor productivity growth estimates, we measure the growth in sectorial labor, human capital, physical capital, and the levels of sectorial land, capital, and labor shares. Using our adjusted data, we then conduct two growth accounting exercises. First, we decompose the growth of total output in each sector into the contributions of labor, human capital, physical capital, and total factor productivity growth. Second, we decompose the growth of aggregate labor productivity (output per labor) into the contributions of agricultural labor productivity growth, the reallocation of labor from agriculture to nonagriculture; private and public nonagricultural labor productivity growth, and the reallocation of labor from the public to the private nonagricultural sector. In Section 3, we develop our model economy, and analyze its properties. In Section 4 , we calibrate our model to reasonable parameter values and compare the model with patterns in the Chinese data. In Section 5, we use our model, and our long-run projections of the exogenous variables for the Chinese economy, to conduct forecasting experiments. Section 6 concludes.

\section{The Data}

All data cited in this Section, unless otherwise noted, are from the annual issues of the Chinese Statistical Yearbook (CSY), issued by the State Statistical Bureau (SSB). Views among Chinese economy specialists differ as to the reliability of Chinese official economic statistics. Young (2003) and Rawski (2004) argue that GDP (output) growth is systemat- 
ically overstated by the official statistics, while investment is understated. Chow (1993), on the other hand, argues that Chinese official statistics are on the whole reliable. It is beyond the scope of this paper to judge these arguments regarding the accuracy of Chinese official statistics. In general, we accept the Chinese official statistics, making adjustments only in cases when the deficiencies of the commonly used measures (such as in GDP and in investment) are well known.

For our purposes, the main challenge is to classify the Chinese data into our three sectors of interest: the agricultural sector, the nonagricultural public sector, and the nonagricultural private sector. The agricultural sector is defined as the primary industry, which includes forestry, livestock, and fishing. The nonagricultural sector is defined as the sum of the secondary and tertiary industries. In the nonagricultural public sector, we include State-owned enterprises, Collective and Cooperative units, and Township and Village enterprises (TVEs). The nonagricultural private sector includes all other types of firms, including Private enterprises, Self-employed workers, and firms with foreign investment.

Unlike in capitalist economies, in China, there are conceptual difficulties in classifying firms into the public and private sectors. In particular, Township and Village enterprisesthe largest employer in China since the early 1990s (about 135 million workers)-are owned and operated by local governments. Much has been made about how these TVEs owned by local governments actually operate like private corporations. Although China's local governments may try to operate a miniature state-run economy, ultimately each local producer is subjected to competition from thousands of other villages. In this competitive environment, each local government faces a relatively hard budget constraint; and has to make its own enterprise economically successful (Naughton, 2005). On the other hand, local governments do serve as guarantors of TVE borrowing. If that is the case, then capital allocation decisions by TVEs are not determined entirely by the market. In fact, continued government interference, and corruption are described as disadvantages of local government ownership. These disadvantages of local government ownership seem to have worsened since the mid-1990s, as employment and profitability in the TVEs have declined (Naughton, 2005). While acknowledging that the TVEs may be subject to some market forces, we classify TVEs as belonging to the public sector, since ultimately, the (local) government decides how much labor and capital that these firms employ.

In fact, even in firms with corporate forms that we classify as belonging to the private sector-such as limited liability and shareholding corporations-the government often owns significant equity stakes. When a State-owned enterprise is privatized, the privatized enterprise often takes the form of a limited liability or shareholding corporation. The corporate boards of these firms are often dominated by government officials. Thus, the government may exercise significant legal control over the investment and employment decisions of even 
these privatized enterprises (OECD, 2005). ${ }^{1}$

\subsection{Employment by Sector}

Total employment in State-owned enterprises, Collective and Cooperative units, TVEs, Private and other firms, and the Self-employed are given in the CSY. The CSY also gives the number of employees in each of these sectors that work in agriculture, so we can net out agricultural employment from total employment; and calculate the number of nonagricultural workers in public and private enterprises. ${ }^{2}$

Figure 1 depicts the shares of employment, since 1978. Particularly noteworthy is the decline in the relative share of agricultural employment from 70 percent of all workers in 1978 to less than 50 percent of all workers in $2003 .^{3}$ The share of workers in private industry has increased from a negligible level in the mid-1980s to approach about 25 percent of all workers in 2003. The share of workers in public industry, while increasing until the mid1990s, declined sharply since the late 1990s, as State enterprises and TVEs were privatized.

\subsection{Prices and GDP by Sector}

We follow Young's (2003) methodology by deflating the nominal GDPs reported in the $C S Y$ not by their GDP deflators, but by other survey based price indices, reported in the $C S Y$. We deflate primary sector nominal GDP by the general price index of farm products. We deflate secondary sector nominal GDP by the ex-factory industrial price index. We deflate tertiary sector nominal GDP by the service price index.

Figure 2 depicts the ratio of the general price index of farm products ("agricultural prices") to the industrial price index ("industry prices"). For "industry prices," we take the weighted average of the ex-factory industrial price index and the service price index, where the weights are the nonagricultural GDP shares of the secondary and tertiary sectors.

\footnotetext{
${ }^{1}$ Although China bans the direct involvement or participation of government officials in any commercial activities, in reality many government officials and their relatives invest in private enterprises.

Also, because of the lack of strong legal protection of private property, private enterprises often have to seek this protection from local government officials. With this protection, private enterprise can more easily obtain loans from banks. Naturally, this means that there is some meddling in the affairs of private enterprises by government officials (Asian Development Bank, 2003).

${ }^{2}$ Brandt, Hsieh, and Zhu (BHZ, 2005) suggest that the number of agricultural workers reported in the CSY is upward biased, because the CSY assumes that all rural workers are employed in agriculture, when in fact, some rural workers are self-employed or employed in rural industry. BHZ subtract from the total number of agricultural workers, the number of rural workers involved in self-employment and in private enterprises. BHZ's procedure, however, may understate the number of agricultural workers, to the extent that many rural workers have dual jobs, in both agriculture and nonagriculture. Because of the inherent difficulty in classifying rural workers, here we take "as is" the CSY classification of agricultural and nonagricultural workers.

${ }^{3}$ In late 2005, the output of the service sector was revised upwards, reflecting the growth in law and consulting firms, retail stores, health clubs, and the like. Most of this output is believed to be generated by private firms, especially individual proprietors. Our estimates of employment do not capture this latest revision in the growth of the nonagricultural sector (Manchester Guardian, 2005).
} 
The ratio of agricultural prices to industry prices increased until the late 1980s, and then declined by about 60 percent from then on to return to the 1978 level.

China's agricultural prices have been gradually liberalized from government control since the early 1980s. In the early 1980s, to increase incentives to farmers, China's leaders sharply increased the procurement prices of agricultural goods (McMillan, Whalley, and Zhu, 1989; Huang, Otsuka, and Rozelle, 2004). Since then, the government has periodically intervened through procurement plans at least until the early 1990s. Thus, only from about the early 1990s are Chinese agricultural prices largely determined by the market. We can see from Figure 2 that the ratio of agricultural to industry prices has generally declined from 1990, when agricultural prices became more market determined.

On the other hand, Brandt, Hsieh, and Zhu (2005) argue that the decline in the relative price of agriculture since 1990 is overstated in the data as depicted in Figure 2. This is because the service price index used to construct the price index for nonagricultural or industry prices is likely to overestimate the actual price increases in the services sector, owing to rapid structural shifts in the Chinese economy from personal to business services. The authors construct an alternative price index for services, and show that by using this new service price index, the ratio of agricultural to industry prices from 1990 is essentially flat. Given the inherent data problems in measuring the change in service prices in China, we are agnostic about the whether the ratio of agricultural prices to industry prices is falling or relatively flat from the 1990s.

The $C S Y$ does not break down GDP, a value added measure, into the public and private sectors for our entire sample period. ${ }^{4}$ However, it breaks down nonagricultural gross output into the State-owned, Collective, Cooperative, TVE, and the Private sectors; so that nonagricultural gross output can be allocated to each of these sectors. We make the assumption that the share of intermediate inputs is the same in all sectors; so that the ratio of net to gross outputs are the same. ${ }^{5}$ We then simply allocate total nonagricultural GDP to the public and private sectors; according to the allocation of gross outputs.

Figure 3 depicts the growth in total output, and its breakdown from 1978 to 2003. While growing strongly since 1978, total output growth stalled in the late 1980s. In 1989, total output fell by over 5 percent. Young (2003) correlates the late 1980s slowdown in total output growth to the student uprisings in Tiananmen Square. Total output growth has been especially strong since 1999, growing at over 9 percent, even according to our lower revised growth rates (compared to the official growth rates). Particularly noteworthy is the sharp increase in the share of the output of private industry since the mid-1990s.

\footnotetext{
${ }^{4}$ In late 2005, Chinese growth rates from 1995 to 2004 were revised upwards because of the increased estimated output in some private sector tertiary (service) industries, such as in law and advertising (Manchester Guardian, 2005). Our data do not reflect these recent upward revisions in the shares of the service sector.

${ }^{5}$ This is not a bad assumption; especially after 2000, where we have data on GDPs for both State-owned and Private firms. In 2002, the ratios of GDP to gross output were about 0.70 in both sectors.
} 
Figure 4 depicts the trends in labor productivity. The data on private industry labor productivity are rather volatile, jumping in 1986, and fluctuating sharply between 1990 and 1997. This may be a result of poor sectorial output data; or that in earlier years, the share of private industry was small in China, so that the privatization of some huge State enterprises may have lead to large changes in average private industry labor productivity. We thus put more credence on the long-run trends in Chinese labor productivity, than on the year-to-year fluctuations.

Average aggregate labor productivity (output per labor) in our revised data grew at 5.7 percent per annum between 1978 to 2003. Average agricultural labor productivity grew at 4.5 percent per year, from 300 yuan per worker in 1978 to 1100 yuan per worker in 2003. Average nonagricultural (industry) labor productivity grew at 4.1 percent, from 2200 yuan per worker in 1978 to 5900 yuan per worker in 2003, with annual public and private industry labor productivity growing at 2.6 percent and 7.5 percent, respectively.

We can determine the contribution of agricultural and nonagricultural labor productivity to the growth in aggregate GDP per worker by performing a simple accounting exercise. Of the 5.7 percent per annum growth in aggregate GDP per worker productivity, the contribution of agricultural labor productivity growth was 0.8 percent, and the contribution of nonagricultural labor productivity growth was 3.0 percent. ${ }^{6}$ The remainder-1.9 percent-is the contribution of the reallocation of labor, from the low labor productivity agricultural sector to the high labor productivity nonagricultural sector.

Agricultural labor productivity, while growing three-fold since 1978, even now (in 2003) is only about $1 / 6$ of average nonagricultural labor productivity. This suggests that the scope of raising the aggregate productivity of labor by transferring low productivity agricultural workers to the high productivity nonagricultural sector remains large.

\subsection{Capital and Land by Sector}

Total gross fixed capital formation (GFCF) is obtained from the CSY. The published Chinese national accounts do not provide information on the sectorial distribution of GFCF, but the provincial accounts do. For the period 1978-95, Hsueh and Li (1999) report the sectorial distribution of GFCF in 26 provinces (all provinces other than Jianxi, Guangdong, Hainan, and Tibet), accounting for an average of 78 percent of the annual value of national GFCF. For the remaining period 1996-2003, we obtain the distributional gross fixed capital formation data from the individual Provincial Statistical Yearbooks, and aggregate across the provinces. We use the sectorial distribution reported in Hsueh and Li (1999) and in the Provincial Statistical Yearbooks to allocate overall national gross capital formation between the agricultural and nonagricultural sectors of the economy.

\footnotetext{
${ }^{6}$ The contribution of the primary and nonprimary sectors are measured by the growth of labor productivity in each sector, weighted by their respective shares of GDP.
} 
The $C S Y$ provides additional data on fixed investment by ownership (State, TVEs, Collective, private, etc.) in the nonagricultural sector. This additional data is compiled from enterprise surveys; and its magnitude is about 10 percent higher than the national income account gross fixed capital formation data, from at least the late 1990s. The coverage of fixed investment in these enterprise surveys seems quite comprehensive, and includes investment in capital construction, research and development, real estate development, and in other areas. We assume that the discrepancy between the fixed investment data and the national income accounts gross capital formation data are identical across sectors; and use the sectorial distribution in the data on fixed investment to allocate nonagricultural gross capital formation between the public and private sectors of the nonagricultural economy.

To obtain our real investment figures, we must deflate our nominal investment figures. Between 1978 and 1998, we deflate our measures of nominal sectorial investment with Young's (2003, Figure 5) alternative deflator for gross fixed capital formation. Between 1999 and 2003, we construct our own alternative deflator, following the method of Young (2003). With our measures of real sectorial investment from 1978 to 2003 in hand, we can calculate the capital stock using the perpetual inventory method and a 5 percent depreciation rate (as in Young (2003)). We obtain the starting stock of capital at the end of 1978 from Chow (1993).

Figure 5 depicts the capital-output ratios for the economy, and by sector. The capitaloutput ratio for the entire economy has remained constant at about 4 since 1978. That capital deepening has not occurred for China in the post-reform period is well known (Young, 2003). The capital-output ratio of public industry has risen since the mid-1990s, reflecting the low productivity of capital in State enterprises and in the TVEs in recent years. In contrast, the capital-output ratio of private industry is falling, reflecting the higher efficiency of capital in private industry.

Figure 6 depicts the investment shares of the agricultural, public and private industrial sectors. The investment share of the agricultural sector has declined at a gradual pace. Since the early 1990s, the investment share of public industry has sharply declined; while that for private industry has sharply increased. These trends reflect the growth of private industry, and the relative decline of public industry. However, the level of the capital stock in public industry has continued to rise, as evidenced by the recent decline of the capital-output ratio in that industry.

Finally, while we assume that labor and capital are the only two inputs in the nonagricultural sector, we allow land inputs in the agricultural sector. We measure total land inputs by the total sown area of farm crops in China (as in McMillan, Whalley, and Zhu, 1989). These data are available in the $C S Y$. The total sown area of farm crops has remained essentially fixed, growing at an annualized rate of 0.06 percent between 1978 and 2003. 


\subsection{Growth in Human Capital by Sector}

A proper measure of the growth of labor input should account for differences in the human capital of the workforce. For example, suppose that overall labor services are a constant returns to scale function of $\mathrm{N}$ types of labor:

$$
L=H\left(L_{1}, L_{2, \ldots} L_{N}\right)
$$

Differentiating, the growth of overall labor services is a weighted average of the growth of each type of differentiated labor:

$$
\frac{d L}{L}=\sum_{i} \frac{H_{i} L_{i}}{L} \frac{d L_{i}}{L_{i}}
$$

where the human capital weight $H_{i}$ is revealed by the wage of worker of type $i$.The difference between $\frac{d L}{L}$ and the growth of overall labor undifferentiated by type can be taken as the contribution of "human capital."

While the CSY provides a reasonable measure of the overall growth of the labor force, and its sectorial distribution, it does not contain any information about the characteristics of workers, such as sector, age, and education needed in the calculation of $L_{i}$. To adjust for the changing characteristics of workers, we must use Chinese census and survey data. We obtain the number of workers by sector, age and education from the 1987 Tabulation of China's 1\% Population Sample Survey and the 2000 Population Census of China. (Published Chinese census data prior to 1987 do not provide education levels broken down by age.) We classify workers into 11 age, 4 education, and 2 sector (agriculture, nonagriculture) categories to obtain a total of 88 characteristics. By taking the annualized growth rate in the number of workers of characteristic i between 1987 and 2000, we can obtain the growth rate of workers of characteristic i, $\frac{d L_{i}}{L_{i}}$.

These growth rates must weighted by $H_{i}$, or by wages. Predicted wages of workers of characteristic i are obtained in the usual way from estimated Mincer equations for Chinese workers. We calculate the growth in human capital separately for the agricultural and nonagricultural sectors. For nonagricultural workers, we use the Mincer equation estimated by Young using Chinese household level data (2003, Table 17). Reliable estimates of Mincer equations for Chinese agricultural workers do not exist. This is because Chinese farms are generally operated by families-not paid workers-who subsist by keeping a portion of agricultural proceeds, according to the household responsibility system (Huang, Otsuka, and Rozelle, 2004). Thus, for the predicted wages of those employed in the Chinese agricultural sector, we use Mincer equations estimated for employees in Chinese rural industry, on the assumption that on the margin, the wages of employees in rural industry should capture the marginal revenue product of Chinese agricultural workers. For these 
employees in rural industry, we use the Mincer equation estimated by Zhang, Huang, and Rozelle (2002). The estimated returns to education for employees in Chinese rural industry are considerably lower than the returns to education for the general sample of Chinese nonagricultural workers.

We subtract from our calculated $\frac{d L}{L}$ for the agricultural and nonagricultural sectors, the growth in the overall labor forces in these sectors between 1987 and 2000, to arrive at annualized growth rates of human capital of 1.4 percent in nonagriculture, and 1.1 percent in agriculture. Given the lack of appropriate Chinese census data spanning other periods, we assume that these growth rates hold on average for the entire period 1978 to 2003 . Since we do not have the characteristics of workers by type of nonagricultural industry, we assume identical growth rates of human capital for both the public and private sectors of Chinese industry.

\subsection{Factor Income Shares by Sector}

In China, the ratio of compensation by employees to GDP can be estimated using data from the Provincial Statistical Yearbooks or from the input-output tables. Young (2003, Table 21) finds that on average between 1978 and 1995, the labor share of output for the nonagricultural sector was 0.46 using both the provincial or the input-output data. There is clearly an upward trend in the labor share; in the provincial data, it rose from 0.42 in 1978 to 0.53 in 1995. We obtained the Provincial Statistical Yearbooks from 1996 to 2003, and calculated nonagricultural labor shares across Chinese provinces for each year. Between 1996 and 2003, the labor share averaged 0.54. Thus, for the entire period, 1978 to 2003, the nonagricultural labor share averaged 0.46. We assume identical labor shares for the public and private Chinese nonagricultural industries.

Using the provincial data assembled by Hsueh and Li (1999) between 1978 and 1995; and the Provincial Statistical Yearbooks from 1996 to 2003, we find that the average labor share in agriculture was 0.76 for the period 1978 to 2003. This is higher than the 0.53 found by Hayami and Ruttan (1985), using Chinese data in the pre-reform (1978) period; but similar to the 0.70 labor share used in McMillan, Whalley, and Zhu (1989). Hayami and Ruttan (1985) find that the capital share is twice as high as the land share. Chow (1993) estimates a production function for the Chinese agricultural sector using data from 1952 to 1988 and finds that the labor, capital, and land shares are 0.40, 0.25, and 0.35, respectively. Both Hayami and Ruttan (1985) and Chow (1993) include data from the pre-reform (1978) period. It is hard to interpret factor shares based on a period when the economy was centrally planned. Because of the lack of reliable data, here we assume identical capital and land shares in agriculture, 0.12. Changing the capital and land shares to 0.16 and 0.08 only negligibly affects our estimates of agricultural total factor productivity growth. 


\subsection{Total Factor Productivity Growth by Sector}

Table 1 summarizes our accounting of Chinese economic growth from 1978 to 2003. Total factor productivity (TFP) growth is estimated in the usual way:

$$
\text { TFP Growth }=\frac{d Y}{Y}-w_{k} \frac{d K}{K}-w_{L} \frac{d L}{L}-w_{T} \frac{d T}{T}
$$

where $w_{k}$ is the capital share, $w_{L}$ is the labor share, and $w_{T}$ is the land share. We have shown above that the capital share is 0.12 for agriculture, and 0.54 for nonagriculture; the labor share is 0.76 for agriculture, and 0.46 for nonagriculture; and the land share is 0.12 for agriculture.

TABLE 1: Accounting for Total Factor Productivity Growth (1978-2003; in percent per annum)

\begin{tabular}{lrrrrr}
\hline & Aggregate & Agriculture & Nonagriculture & Public & Private \\
Output & 8.4 & 5.6 & 9.1 & 5.2 & 24.2 \\
Labor & 2.5 & 1.0 & 4.8 & 2.5 & 15.5 \\
Human Capital & - & 1.1 & 1.4 & 1.4 & 1.4 \\
Physical Capital & - & 3.5 & 8.1 & 6.5 & 16.8 \\
Agricultural Land & - & 0.06 & - & - & - \\
Total Factor Productivity & - & 3.5 & 1.9 & -0.05 & 7.3 \\
& & & & & \\
Output per Labor & 5.7 & 4.5 & 4.1 & 2.6 & 7.5 \\
Output per Labor (Level) & & & & & \\
(in 100s of 1978 yuan) & & & & & \\
$\quad 1978$ & 9 & 3 & 59 & 42 & 80 \\
\hline
\end{tabular}

We estimate that total factor productivity growth in Chinese agriculture averaged 3.5 percent per annum between 1978 and 2003. McMillan, Whalley, and Zhu (1989) estimate that for the 1978 to 1984 period, total factor productivity growth in Chinese agriculture averaged almost 6 percent. However, this earlier period was marked by enormous increases in agricultural productivity, owing to the introduction of the household responsibility system and administrated increases in agricultural prices, which sharply raised incentives for farming. For the more recent period of 1979 to 1997, Fan and Zhang (2002) find that total factor productivity growth in Chinese agriculture was 3.3 percent per annum, which is close to our estimate.

We estimate that TFP growth in the Chinese nonagricultural sector averaged 1.9 percent per annum between 1978 and 2003. Since our methodology for adjusting Chinese 
statistics follows Young (2003), our estimate of nonagricultural total factor productivity growth is close to the 1.4 per annum Young found between 1978 and 1998. Our estimate is somewhat higher than Young's estimate, since Chinese nonagricultural TFP accelerated between 1999 and 2003. Using unadjusted data from the Chinese national accounts, Li (2003) finds TFP growth of 3.2 per annum between 1978 and 1998. This higher estimate shows that the use of unadjusted Chinese national accounts data-by overestimating GDP growth and underestimating investment-may result in very high TFP estimates.

We find essentially zero, or slightly negative TFP growth in public nonagricultural industries. The finding of negative or very small productivity growth in Chinese state industries is consistent with Jefferson, Rawski, and Zheng (1989), and the OECD (2005). In particular, the OECD (2005) uses a large scale firm level survey conducted by the Chinese government; and finds that from 1998 to 2003, private firms had TFP growth rates between 121 percent and 46 percent higher than firms with varying degrees of state control. However, our definition of public industries include Township and Village Enterprises and other collectives, in addition to State-owned enterprises. As expected and consistent with the OECD's (2005) firm level findings, TFP growth rates in Chinese private nonagricultural industries are very high.

\subsection{Role of the Reallocation of Labor, or of "Structural Transformation"}

We can further examine the role of the reallocation of labor in accounting for Chinese growth. The growth in total output can be broken down into the growth of labor supply; and the growth in aggregate labor productivity (output per labor). The growth in aggregate labor productivity-in turn-can be broken down into the contribution of agricultural labor productivity, of nonagricultural labor productivity; and of the reallocation of labor from low productivity agriculture to high productivity nonagriculture. The contributions of the agricultural and nonagricultural sectors are measured by the growth of labor productivity in each sector, weighted by their respective shares of output. Finally, the contribution of the reallocation of labor is equal to the growth in nonagriculture's share of total employment weighted by the gap in labor productivity between the two sectors, measured as a percentage of aggregate labor productivity.

Of the 8.4 percent growth in aggregate output, the growth in labor productivity contributed 5.7 percent between 1978 and 2003. Of this 5.7 percent, the growth in agricultural labor productivity contributed 0.8 percent; and the growth in nonagricultural labor productivity contributed 3.0 percent. The reallocation of labor from agriculture to nonagriculture contributed 1.9 percent to aggregate and per capita output growth, owing to the low productivity level of agricultural labor, compared to nonagricultural labor. 
TABLE 2: Role of the Reallocation of Labor

(1978-2003; in percent per annum)

\begin{tabular}{lrrr}
\hline & $1978-2003$ & $1978-1995$ & $1996-2003$ \\
Output Growth & 8.4 & 8.5 & 6.8 \\
Labor Growth & 2.5 & 3.2 & 0.9 \\
Output per Labor (Labor Productivity) Growth & 5.7 & 5.2 & 5.8 \\
$\quad$ Contribution of Agricultural Labor Productivity Growth & 0.8 & 0.7 & 0.8 \\
Contribution of Nonagricultural Labor Productivity Growth & 3.0 & 2.4 & 4.7 \\
$\quad$ Of Which: & & & \\
$\quad$ Contribution of Public Sector Productivity Growth & 1.7 & 1.6 & 1.0 \\
$\quad$ Contribution of Private Sector Productivity Growth & 1.0 & 0.6 & 2.7 \\
$\quad$ Labor Reallocation from Public to Private Sector & 0.5 & 0.3 & 1.0 \\
Labor Reallocation from Agriculture to Nonagriculture & 1.9 & 2.0 & 0.2 \\
\hline
\end{tabular}

The role of the reallocation of labor from agriculture to nonagriculture in accounting for overall growth has declined over time. While this reallocation contributed 2.0 percent between 1978 and 1995, it contributed only negligibly (0.2 percent) between 1996 and 2003. On the other hand, the contribution of nonagricultural labor productivity growth has increased sharply, from 2.4 percent in 1978-1995 to 4.7 percent in 1996-2003.

The contribution of nonagricultural labor productivity growth can be further broken down into the contribution of public sector labor productivity growth, of private sector labor productivity growth, and the reallocation of labor from the public to the private sector. The contribution of public sector productivity growth has fallen from 1.6 percent in 1978-1995 to 1.0 percent in 1996-2003. In contrast, the contribution of private sector productivity growth increased from 0.6 percent in 1978-1995 to 2.7 percent in 1996-2003. The contribution of the remainder-the reallocation of labor from the public sector to the higher productivity private sector-contributed 1.0 percent to both aggregate productivity growth and aggregate output growth. Thus, since the mid-1990s, Chinese aggregate productivity and output growth seem to be driven largely by high productivity growth in the private sector, and the reallocation of labor from the public to the private sector.

\section{The Model Economy}

\subsection{Environment}

Consider an economy where time is discrete and indexed by $t=1, \ldots,+\infty$. There is a measure 1 of identical, infinitely-lived households, endowed with 1 unit of productive time each period. Households have preferences defined over two goods: An agricultural good called $a$ and a nonagricultural (manufacturing and service) good called $m$. The latter is 
the numéraire. The price of good $a$ is denoted by $p_{t}$. It is produced by the agricultural sector with the services of labor, capital and land. The stock of productive land, $l$, is fixed and owned by households. (In the data, the agricultural land area is virtually fixed, increasing by a total of less than 1.5 percent in 25 years.) The nonagricultural good is produced by two different entities: a private nonagricultural sector and a public sector run by the government. Both use capital and labor to produce $m$. The private sector rents labor, capital and land from households. Capital depreciates at rate $\delta$ and the interest rate between period $t-1$ and $t$ is denoted by $r_{t}$. The rental rate of capital is then $r_{t}+\delta$. Land is assumed to not depreciate. Its price during period $t$ is denoted by $q_{t}$ and its rental rate between period $t-1$ and $t$ by $i_{t}$. The wage rate during period $t$ is $w_{t}$.

The government is also a producer of good $m$. It has access to the same technology as the private nonagricultural sector, but its total factor productivity can be lower to capture the idea that government's businesses tend to be less efficient than private businesses. How does the government acquires the resources (i.e., capital and labor) needed to operate the nonagricultural technology? It is assumed that it hires labor and pays the market wage, but it does not rent capital. Instead, it accumulates capital through lump-sum taxation, $\tau_{t}$. It does not maximize any objective function: instead, public employment and the level of taxation (i.e., the level of public investment) are determined exogenously and constitute policy variables. The revenue, after paying public workers, is rebated to households as a lump-sum transfer, $T_{t}$.

\subsection{Households}

Preferences are represented by

$$
\sum_{t=0}^{\infty} \beta^{t} U\left(c_{m t}, c_{a t}\right)
$$

where $c_{j t}$ is consumption of good $j(j=a, m)$ during period $t$. The momentary utility function is defined by

$$
U\left(c_{m}, c_{a}\right)=\ln \left(\left[\omega c_{m}^{(\varepsilon-1) / \varepsilon}+(1-\omega) c_{a}^{(\varepsilon-1) / \varepsilon}\right]^{\varepsilon /(\varepsilon-1)}\right), \text { with } \varepsilon>0
$$

The parameter $\varepsilon$ represents the elasticity of substitution between $c_{m}$ and $c_{a}$. The representative households solves the following maximization problem

$$
\begin{aligned}
\max _{\left\{c_{m t}, c_{a t}, k_{t+1}\right\}_{t=0}^{\infty}} & \sum_{t=0}^{\infty} \beta^{t} U\left(c_{m t}, c_{a t}\right) \\
\text { s.t. } & c_{m t}+p_{t} c_{a t}+s_{t+1}+\tau_{t}=w_{t}+\left(1+r_{t}\right) s_{t}+T_{t} \\
& k_{0} \text { given. }
\end{aligned}
$$


The variable $s_{t+1}$ represents savings of the households during period $t$. They consist in capital and land: $s_{t+1}=k_{t+1}+q_{t} l$. In equilibrium, land and capital offer the same return, i.e., $\left(i_{t}+q_{t}\right) / q_{t-1}=1+r_{t}$. Thus, the return on saving is $1+r_{t}$.

\subsection{Private firms}

In the private nonagricultural sector, the technology is given by

$$
y_{m t}=F^{m}\left(k_{m t}, n_{m t}\right)=z_{m t} k_{m t}^{\alpha} n_{m t}^{1-\alpha}, \alpha \in(0,1)
$$

In the agricultural sector it is

$$
y_{a t}=F^{a}\left(k_{a t}, n_{a t}, l\right)=z_{a t} k_{a t}^{\theta} n_{a t}^{\mu} l^{1-\theta-\mu}, \theta, \mu \in(0,1), \theta+\mu \in(0,1)
$$

The variables $n_{j t}$ and $k_{j t}(j=a, m)$ represent, respectively, the fraction of workers in sector $i$ and the capital stock. Total factor productivity can differ across sectors and is given by $z_{j t}$. The nonagricultural sector solves

$$
\max _{k_{m t}, n_{m t}}\left\{F^{m}\left(k_{m t}, n_{m t}\right)-w_{t} n_{m t}-\left(r_{t}+\delta\right) k_{m t}\right\}
$$

and the agricultural sector solves:

$$
\max _{k_{a t}, n_{a t}, l}\left\{p_{t} F^{a}\left(k_{a t}, n_{a t}, l\right)-w_{t} n_{a t}-\left(r_{t}+\delta\right) k_{a t}-i_{t} l\right\}
$$

Define private capital $k_{t}$ by $k_{t}=k_{a t}+k_{m t}$.

\subsection{Public sector}

The public sector is characterized by a sequence $\left\{n_{g t}, k_{g t}\right\}_{t=0}^{\infty}$ of public employment and capital. Public capital accumulates through

$$
k_{g t+1}=(1-\delta) k_{g t}+x_{g t}
$$

where $x_{g t}$, the level of net public investment, is entirely financed by lump-sum taxes:

$$
x_{g t}=\tau_{t}
$$

Given public employment and capital, the public sector produces a quantity $y_{g t}$ of good $c$, in line with

$$
y_{g t}=z_{g t} k_{g t}^{\alpha} n_{g t}^{1-\alpha} .
$$


Its budget constraint is

$$
w_{t} n_{g t}+T_{t}+k_{g t+1}=y_{g t}+\tau_{t}+(1-\delta) k_{g t}
$$

In words, public expenditures consist of wage payments, transfer payments and the purchase of capital used in the public sector. Public resources are the sum of public production, tax revenue and the value of undepreciated public capital. Since all capital accumulation is financed through taxes, this constraint also writes as

$$
T_{t}=y_{g t}-w_{t} n_{g t}
$$

that is, the government uses its revenue, net of wage payments, to finance transfers to the households.

\section{Definition: Competitive Equilibrium}

Given government's policies $\left\{n_{g t}, k_{g t}\right\}_{t=0}^{\infty}$, an equilibrium is a sequence of prices $\left\{r_{t}, w_{t}, p_{t}, q_{t}, i_{t}\right\}_{t=0}^{\infty}$ and allocations $\left\{n_{m t}, n_{a t}, c_{m t}, c_{a t}, k_{m, t+1}, k_{a, t+1}, l\right\}_{t=0}^{\infty}$ such that

1. Given prices, the sequence $\left\{c_{m t}, c_{a t}, k_{t+1}\right\}_{t=0}^{\infty}$ solves problem (1);

2. Given prices, the sequence $\left\{k_{m t}, n_{m t}\right\}_{t=0}^{\infty}$ solves problem (2);

3. Given prices, the sequence $\left\{k_{a t}, n_{a t}, l\right\}_{t=0}^{\infty}$ solves problem (3);

4. Markets clear:

(a) The market for a clears: $c_{a t}=y_{a t}$;

(b) The market for $m$ clears: $c_{m t}+k_{t+1}+\tau_{t}=y_{m t}+y_{g t}+(1-\delta) k_{t}$;

(c) The labor market clears: $n_{a t}+n_{m t}+n_{g t}=1$.

\subsection{Analysis}

Before we move to the quantitative implications of our model, to fix our intuition, here we analyze the effect of the various driving forces on the agricultural share of employment. The effect of the driving forces at work in the model can be analyzed by investigating its steady state.

Proposition 1 In a steady state, the Equilibrium of the model economy is characterized by a single equation in $n_{a}$ :

$$
C z_{a}^{1-\varepsilon} z_{m}^{(\varepsilon-1) \frac{1-\theta}{1-\alpha}} n_{a}^{(1-\theta-\mu) \varepsilon+\mu+\theta}=\left(1-n_{g}\right)(A-B)-A n_{a}+\frac{G}{z_{m}^{1 /(1-\alpha)}}
$$

where $A, B$ and $C$ are positive constant, depending on the parameters of the model and $G=y_{g}-\delta k_{g}$. 
Proof. See Appendix.

Equation (4) is the market clearing condition for good $m$ where each variable is expressed as a function of $n_{a}$. The right-hand side of (4) is an affine function of $n_{a}$ with a negative slope and a positive intercept. The left-hand side is increasing through the origin. Observe that when $\varepsilon<1$, the coefficient on $n_{a}$ is less than 1 . When $\varepsilon>1$, this coefficient is larger than 1 . In the case where $\varepsilon=1$, or if there were no decreasing returns (or no land) in agriculture, the right-hand side would be a linear function of $n_{a}$. The determination of $n_{a}$ in (a steady state) equilibrium is represented in Figure 7.

Equation (4) reveals that the elasticity of substitution between the two goods is a critical variable of the model. When the goods are substitutes, i.e., when $\varepsilon>1$, the left-hand side of (4) is decreasing in $z_{a}$ and increasing in $z_{m}$, while the opposite is true when $\varepsilon<1$, that is when the goods are complements. Thus, the direction of the effect of $z_{m}$ and $z_{a}$ on the sectorial allocation of labor depends on $\varepsilon$. The mechanism behind this is as follows: When goods are substitutes, a change in the relative price (resulting from changes in $z_{m}$ and/or $z_{a}$ ) leads to an increase in the demand of the cheaper good and a decrease in the demand of the other one. As a result, labor reallocates to the sector experiencing an increase in demand. When the goods are complements, however, a decrease in the relative price leads to an increase in the demand for both goods. To meet this demand, labor reallocates to the sector experiencing the slower growth in productivity. In what follows, the case where $\varepsilon>1$ is analyzed since, in Section $4, \varepsilon$ is calibrated to a value larger than one.

Productivity growth in agriculture - Suppose that there is an increase in total factor productivity in agriculture, $z_{a}$. When the goods are substitutes, an increase in $z_{a}$ reduces the slope of the left-hand side of (4) which creates an increase in $n_{a}$. This is represented in Figure 8.

Productivity growth in private nonagriculture - Now suppose that there is an increase in $z_{m}$. There are two effects. The first one parallels the impact of an increase in agricultural TFP but, here, draws labor out of agriculture. The second effect is linked to the existence of the government, which is another producer of good $m$. An increase in $z_{m}$ makes the private sector relatively more efficient than the public sector, and promotes a reallocation of labor toward the private sector's producing $m$. Observe that this second mechanism operates regardless of the value of $\varepsilon$, but is reinforced, when $\varepsilon>1$, by the fact that consumption of good $a$ decreases (the first effect). The decline in $n_{a}$ is depicted in Figure 9.

Increase in public nonagricultural production - The public sector enters the right-hand side of Equation (4) through its effect on the intercept. The term $G=y_{g}-\delta k_{g}$ is the part of the total consumption of $m$ which is satisfied by public production. One cannot say, a priori, whether an increase in $k_{g}$ raises or reduces $G$. At a sufficiently high level of public capital accumulation, the marginal product of capital is low enough so that an increase in $k_{g}$ decreases $G$. In such case, the employment share in agriculture decreases. This is 
represented in Figure 10. The effect of a increase in public employment, $n_{g}$, is ambiguous for similar reasons: On the one hand, it raises the public production of $m$. On the other hand, less labor is available for working in the private sector producing either $m$ or $a$.

\section{Quantitative Analysis}

In this Section, we will examine if our model is capable of replicating some stylized patterns in the post-reform Chinese economy. Can the model capture the changes in employment shares between agriculture and nonagriculture? How about the changing levels of labor productivity (output per labor) in the three sectors? The nature of the computational experiment is as follows. Suppose first that preference and technology parameters are given. The exogenous driving forces of the economy are productivity paths $\left\{z_{m t}, z_{a t}, z_{g t}\right\}$ and paths for the policy variables, $\left\{k_{g t}, n_{g t}\right\}$. Imagine starting the economy off at date $t=1$, corresponding to 1978, when the levels of productivity and public policy are given by $z_{m 1}, z_{a 1}, z_{g 1}, k_{g 1}$ and $n_{m 1}$. Given a path for the exogenous driving forces, one can compute the equilibrium trajectory of the economy, and assess the extent to which the mechanisms embedded into the model can account for the transition experienced by China.

To build the path of exogenous variables, proceed as follows. First, the government's actual share of total employment in the data (see Figure 1) is used for $n_{g t}$. Second, in the data the stock of capital owned by the government increases at an annual rate of $6.5 \%$ between 1978 and 2003 (see Table 1). Given an initial capital stock $k_{g 1}$, the path for $k_{g t}$ is built as:

$$
k_{g t}=k_{g 1} e^{0.065(t-1)}
$$

The productivity paths $\left\{z_{m t}, z_{a t}, z_{g t}\right\}$ are assumed to grow at constant rates $\gamma_{m}, \gamma_{a}$ and $\gamma_{g}$ respectively:

$$
z_{j t}=z_{j 1} e^{\gamma_{j} t}, j=m, a, g
$$

The $\gamma_{j}$ s are derived from the information provided in Table 1 regarding the growth in Total Factor Productivity and human capital. Namely

$$
\begin{aligned}
\gamma_{m} & =0.073+(1-\alpha) \times 0.014 \\
\gamma_{a} & =0.035+\mu \times 0.035 \\
\gamma_{g} & =-0.005+(1-\alpha) \times 0.014
\end{aligned}
$$

Factor shares $\alpha, \mu$ and $\theta$ were discussed in Section 2.6. The annual depreciation rate is set to $5 \%$, the discount factor $\beta$ to $1 / 1.07=0.93$.

The initial values $z_{m 1}, z_{a 1}, z_{g 1}$ and $k_{g 1}$ are chosen so that the model displays reasonable results along the following dimension: (i) The level of output per labor in the manufacturing sector in 1978 is the highest in the public sector, above that of the private nonagricultural 
sector. Output per labor is the lowest in the agriculture sector (see Table 1); (ii) by 2003, the ranking of output per labor is different, the agricultural sector still is the lowest, but the private nonagriculture sector is the highest (see Table 1); (iii) The employment share in agriculture declines from $70 \%$ to $49 \%$; (iv) The public share of total investment declines from $79 \%$ to $52 \%$; (v) The relative price of agricultural goods declines. The calibrated values of the parameters are summarized in Table 3.

\begin{tabular}{ll}
\hline \hline \multicolumn{2}{l}{ TABLE 3: Calibration } \\
\hline Preferences & $\beta=0.93, \omega=0.20, \varepsilon=2.0$ \\
Technology & $\alpha=0.54, \theta=0.12, \mu=0.76, \delta=0.05$ \\
Driving variables & $z_{m 1}=1.5, \gamma_{m}=0.079$ \\
& $z_{a 1}=5.0, \gamma_{a}=0.061$ \\
& $z_{g 1}=1.4, \gamma_{g}=0.011$ \\
& $k_{g 1}=50, k_{g t}=k_{g 1} e^{0.065(t-1)}$ \\
& $\left\{n_{g t}\right\}$ actual data \\
\hline
\end{tabular}

Figures 11-14 display the simulated paths for the employment share in agriculture, output per labor in each sector, the public share of total investment, and the relative price of agricultural goods. Under this calibration, the model generates a transition of the labor force out of agriculture and towards private nonagriculture. This trend generated by the model economy matches well the level and pace of its empirical counterpart. The patterns of output per labor are also in line with the data in the sense that the ranking and relative pace of sectorial output per labor are consistent. Namely, the agricultural sector is uniformly below the rest of the economy and output per labor grows at the fastest rate in the private nonagricultural sector.

Private investment, in the model economy, grows fast enough so that the share of public investment in total investment is decreasing at a pace that mimics its empirical counterpart. In this respect, the calibration captures the relative disengagement of the state from the economy, and its effect on the sectorial allocation of labor. Finally, the model generates a decline in the relative price of agricultural goods. ${ }^{7}$ However, this decline is more gradual than the decline in the relative price of agricultural goods after the early 1990s, as observed in the data.

\footnotetext{
${ }^{7}$ Note that the (model) relative price plotted in Figure 15 is not $p_{t}$. The model's couterpart to the relative price observe in the data is not the price of $a$ in terms of $m$, but in terms of a bundle of goods. Thus, the relative price of $a$, plotted in Figure 15, is $p_{t} c_{a t} /\left(c_{m t}+p_{t} c_{a t}\right)$.
} 


\section{$5 \quad$ Projections of Future Sectorial Labor Productivities and the Allocation of Labor}

\subsection{Future Path of Exogenous Variables}

We use our model economy developed above to project the future path of Chinese growth in output per labor, and of the country's reallocation of labor, from the agricultural to the nonagricultural sector, and from the public to the private sector. To do this, we must specify the future growth path of the exogenous variables. The exogenous variables in our model are total labor supply, human capital, public employment, public capital; and TFP growth in the agricultural sector, and in the public and private nonagricultural sectors. Table 4 summarizes our assumptions concerning the growth rates of these variables.

\begin{tabular}{ll}
\hline \hline \multicolumn{2}{l}{ TABLE 4: Long-run Projections of Exogenous Variables } \\
(growth in percent per annum) \\
\hline The Exogenous Variable & Long-run Growth \\
Labor & 0.3 \\
Public Employment (Share) & 1) 28 percent of total employment \\
& 2) 5 percent of total employment by 2050 \\
Public Capital & Changes to keep capital-labor ratio \\
& constant under 1) and 2). \\
Human Capital & 0.5 \\
Agriculture & 0.5 \\
Nonagriculture & \\
TFP & 0.7 \\
Agriculture & 0 \\
Nonagriculture & 1.4 \\
Public &
\end{tabular}

Macrochina, a Chinese government research institute affiliated with the State Development Committee, projects that the Chinese total labor force will grow at an average annual rate of about 0.3 percent until 2050. The Macrochina projection is more optimistic than the United Nations population projection for China, which predicts a declining working age population (falling at an annual rate of 0.4 percent until 2050). The United Nations projection assumes that China will continue with the current, general "one-child" policy, while the Macrochina projection assumes a partial discontinuation of the "one-child" policy. (There is a government proposal pending to allow all Chinese couples each of whom is a single child to have two children.) We adopt the more optimistic Macrochina (2006) projection. 
The Chinese government does not release figures for the future pace of privatization of public enterprises. Between 1996 and 2003, the number of workers in public industry decreased by an average of 3.5 percent per year. The government's 11th five-year plan, adopted in March 2006, highlighted the need for continued reform of State-owned enterprises. The plan stated that except for a very few firms key to national security or welfare, State- and Collective-owned enterprises should generally be at least partially privatized. On the other hand, there have been recent calls by some Hong Kong-based economists that the pace of privatization has been too rapid, leading to income inequality and corruption (RIETI, 2004). These calls for a slowdown in privatization appears to have gained some traction in the last few years. Since it is difficult to gauge the Chinese government's privatization plans, we perform our projections under two scenarios. One, we assume that the government keeps the public employment share constant at the 2003 level of 28 percent. Two, we assume that the government reduces the public employment share to 15 percent by 2010 , and to 5 percent by 2050 . We also assume that public capital grows at a rate to keep constant, the public sector capital-labor ratio, under the two scenarios.

In terms of purchasing power parity, China's current per capita income, at $\$ 3750$, is about equal to Japan's per capita income in 1960, its closest industrialized country neighbor. In our projections, we will illustrate what would happen to China's economy if its education levels and productivity growth rates converged to Japan's current (year 2000) values in about 40 to 50 years. While the share of Chinese employees with a secondary education is high, the share of employees with a college education is much lower in China than in Japan. In 2000, the average years of education for the working age population in Japan was 12.4, while in China, it was 10.4. Since typically, the returns to education is about 0.07 for education beyond the secondary level, for Chinese education levels to catch up to Japanese levels in about 40 years, human capital will have to grow at about 0.5 percent per year.

Over the long-run (in 40 to 50 years), we assume that Chinese total factor productivity growth rates in the agricultural and in private nonagricultural industries will gradually converge to industrialized country TFP growth rates, as typified by Japan. Jorgenson and Nomura (2005) estimate that annual Japanese TFP growth rates over the long-run (19602000) averaged 0.70 percent in agriculture; and 1.4 percent in nonagriculture. We take these TFP growth rates as the long-run Chinese TFP growth rates for the agricultural and nonagricultural private sectors. For the Chinese nonagricultural public sector, we assume that in the long-run, TFP growth continues to be about zero.

\subsection{Projections}

The time paths of the projected exogenous variables are fed into the model economy as follows. The growth rates of $z_{m}, z_{a}, z_{g}$ and $k_{g}$ are set to their historical values (see Table 
3) from 1978 until 2009. From 2030 until 2050, they are set to the long-run projections exhibited in Table 4. From 2010 until 2029, they are set to the average of their historical values and their long-run values. The time path of public employment is given by the data until 2003 and, in the first exercise, it is assumed to remain constant at its 2003 value until 2050. Table 5 reports the results of this exercise for the sectorial allocation of labor, sectorial output per labor, and total output per labor. The last four results are each normalized to one in 2005.

\begin{tabular}{|c|c|c|c|c|c|c|c|}
\hline & \multicolumn{3}{|c|}{ Employment Shares } & \multicolumn{3}{|c|}{$\begin{array}{c}\text { Sectorial Output } \\
\text { per Labor }\end{array}$} & \multirow[t]{2}{*}{$\begin{array}{c}\text { Total Output } \\
\text { per Labor }\end{array}$} \\
\hline & Sector $a$ & Sector $m$ & Sector $g$ & $\begin{array}{l}\text { Sector } a \\
2005=1\end{array}$ & $\begin{array}{l}\text { Sector } m \\
2005=1\end{array}$ & $\begin{array}{l}\text { Sector } g \\
2005=1\end{array}$ & \\
\hline 2010 & 0.33 & 0.39 & 0.28 & 1.23 & 1.70 & 1.24 & 1.88 \\
\hline 2020 & 0.26 & 0.46 & 0.28 & 1.46 & 4.28 & 2.80 & 5.36 \\
\hline 2030 & 0.20 & 0.52 & 0.28 & 1.63 & 10.10 & 2.57 & 14.17 \\
\hline 2040 & 0.16 & 0.56 & 0.28 & 1.58 & 17.26 & 3.46 & 25.53 \\
\hline 2050 & 0.14 & 0.58 & 0.28 & 1.57 & 26.12 & 4.66 & 40.04 \\
\hline
\end{tabular}

One can read Table 5 as follows: Under the scenario detailed above, the Chinese total output per labor would be multiplied by a factor 1.88 between 2005 and 2010 . This amounts to an annual growth rate of $12 \%$, a figure much higher than the average $5.7 \%$ annual growth in labor productivity observed since 1978. The growth rate of labor productivity declines in the long run to average $7.6 \%$ from 2010 until 2050. The main driver of this labor productivity expansion is the continued high TFP growth in the private sector. Along this path, the structural transformation would continue; and the agricultural share of employment would decline to $14 \%$ of the labor force.

Suppose now that the Chinese government reduces public employment gradually to reach $5 \%$ of the labor force by 2050 . How would this affect the structural transformation of the economy? Table 6 reports the results of this experiment. Here, the path of $n_{g}$ is assumed to equal its current value (about 0.28) until 2009. From 2010 until 2029, it is set to 0.15 and from 2030 on, it is set to 0.05 . 


\begin{tabular}{|c|c|c|c|c|c|c|c|}
\hline \multirow{2}{*}{ TABL } & 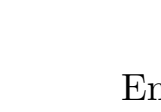 & 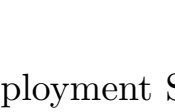 & 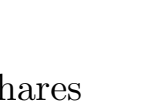 & \multicolumn{3}{|c|}{$\begin{array}{c}\text { Sectorial Output } \\
\text { per Labor }\end{array}$} & \multirow{2}{*}{$\begin{array}{l}\text { Total Output } \\
\text { per Labor } \\
2005=1\end{array}$} \\
\hline & Sector $a$ & Sector $m$ & Sector $g$ & $\begin{array}{l}\text { Sector } a \\
2005=1\end{array}$ & $\begin{array}{l}\text { Sector } m \\
2005=1\end{array}$ & $\begin{array}{l}\text { Sector } g \\
2005=1\end{array}$ & \\
\hline 2010 & 0.39 & 0.46 & 0.15 & 1.21 & 1.58 & 1.73 & 2.06 \\
\hline 2020 & 0.31 & 0.54 & 0.15 & 1.43 & 4.19 & 2.52 & 6.21 \\
\hline 2030 & 0.26 & 0.69 & 0.05 & 1.55 & 9.32 & 6.47 & 17.23 \\
\hline 2040 & 0.23 & 0.72 & 0.05 & 1.49 & 16.03 & 8.71 & 31.07 \\
\hline 2050 & 0.23 & 0.72 & 0.05 & 1.47 & 22.73 & 11.72 & 43.72 \\
\hline
\end{tabular}

When public employment is reduced, labor is reallocated to both the agricultural and nonagricultural sectors. The share of employment in agriculture in 2050 under this new scenario is $23 \%$ (compared with $14 \%$ under the previous scenario). Similarly, the share of nonagricultural employment is higher: $72 \%$ vis à vis $58 \%$. In terms of overall labor productivity growth, the two experiments just described hardly differ: The predicted annual growth rate of total output per labor in the second experiment is $7.6 \%$ between 2010 and 2050 , as it is in the first one.

\section{Conclusions}

We have shown in the simulations above that our model economy captures the most salient features of the Chinese economy since the reform period starting in 1978. The model captures well, the structural transformation of China, the reallocation of labor from agriculture to nonagriculture, and the patterns of labor productivity growth in the agricultural, private, and public sectors. The projection exercises above imply that labor productivity growth in the private sector-and in the entire economy- will continue to be high in China. Under the scenario that the employment share of the Chinese public sector continues to shrink, this dynamic private sector will comprise about 70 percent of total employment by 2030. We project the average growth in total labor productivity to be about 7.6 percent between 2010 and 2050. Total GDP growth between 2010 and 2050 should average about 7.9 percent annually (7.6 percent growth in output per labor plus 0.3 percent average annual growth in labor supply).

\section{Appendix}

FIRMS 
The first order conditions for private firms imply

$$
\begin{aligned}
r+\delta & =\alpha z_{m}\left(\frac{k_{m}}{n_{m}}\right)^{\alpha-1}=\theta p z_{a} k_{a}^{\theta-1} n_{a}^{\mu} \\
w & =(1-\alpha) z_{m}\left(\frac{k_{m}}{n_{m}}\right)^{\alpha}=\mu p z_{a} k_{a}^{\theta} n_{a}^{\mu-1}
\end{aligned}
$$

or $\mathbf{k}_{a}=\Sigma \mathbf{k}_{m}$ where $\mathbf{k}_{a}=k_{a} / n_{a}, \mathbf{k}_{m}=k_{m} / n_{m}$ and $\Sigma=(1-\alpha) \theta /(\alpha \mu)$. Combine the first order conditions for $k_{m}$ and $k_{a}$ to obtain

$$
p=\frac{\alpha}{\theta} \frac{z_{m}}{z_{a}} \mathbf{k}_{m}^{\alpha-\theta} \Sigma^{1-\theta} n_{a}^{1-\theta-\mu}
$$

\section{HouseHolds}

The first order conditions with respect to $c_{m}$ and $c_{a}$ imply

$$
\frac{c_{m t}}{c_{a t}}=\left(\frac{\omega}{1-\omega}\right)^{\varepsilon} p_{t}^{\varepsilon}
$$

while the first order condition with respect to $s_{t+1}$ writes $\lambda_{t}=\lambda_{t+1}\left(1+r_{t+1}\right)$ where $\lambda_{t}$ is the Lagrange multiplier associated with the period budget constraint. In the steady state, this is $r=1 / \beta-1$.

MARKET FOR M

Write the budget constraint of a household as

$$
\begin{aligned}
c_{m t}+p_{t} c_{a t}+s_{t+1}+\tau_{t} & =w_{t}+\left(1+r_{t}\right) s_{t}+T_{t} \\
& =w_{t} n_{m t}+w_{t} n_{a t}+w_{t} n_{g t}+\left(1+r_{t}\right)\left(k_{m t}+k_{a t}+q_{t-1}\right)+T_{t}-\tau_{t}
\end{aligned}
$$

The first order conditions of sector $m$ and $a$ together with the market clearing condition for good $a$ imply

$$
c_{m t}+k_{t+1}=y_{m t}+y_{g t}+(1-\delta) k_{t}-\tau_{t},
$$

in a steady state, this is

$$
c_{m}=\left(y_{m}-\delta k\right)+\left(y_{g}-\delta k_{g}\right) .
$$

The right-hand side of (5) is

$$
y_{m}-\delta k+y_{g}-\delta k_{g}=z_{m} \mathbf{k}_{m}^{\alpha} n_{m}-\delta k+y_{g}-\delta k_{g} .
$$

Write total private capital as $k=\mathbf{k}_{m} n_{m}+\mathbf{k}_{a} n_{a}$ or, using the fact that $\mathbf{k}_{a}=\boldsymbol{\Sigma} k_{m}$ and the 
equilibrium condition on the labor market, $k=\mathbf{k}_{m}\left(n_{m}(1-\Sigma)+\Sigma\left(1-n_{g}\right)\right)$, thus

$$
\begin{aligned}
y_{m}-\delta k+y_{g}-\delta k_{g} & =z_{m} \mathbf{k}_{m}^{\alpha} n_{m}-\delta \mathbf{k}_{m}\left(n_{m}(1-\Sigma)+\Sigma\left(1-n_{g}\right)\right)+\underbrace{y_{g}-\delta k_{g}}_{G} \\
& =n_{m}\left[z_{m} \mathbf{k}_{m}^{\alpha}-\delta \mathbf{k}_{m}(1-\Sigma)\right]-\delta \mathbf{k}_{m} \Sigma\left(1-n_{g}\right)+G
\end{aligned}
$$

In a steady state, $\mathbf{k}_{m}=x z_{m}^{1 /(1-\alpha)}$ where $x=[((1 / \beta)+\delta-1) / \alpha]^{1 /(1-\alpha)}$ thus,

$$
\begin{aligned}
y_{m}-\delta k+y_{g}-\tau & =n_{m}\left[z_{m} x^{\alpha} z_{m}^{\alpha /(1-\alpha)}-x z_{m}^{1 /(1-\alpha)} \delta(1-\Sigma)\right]-x z_{m}^{1 /(1-\alpha)} \delta \Sigma\left(1-n_{g}\right)+G \\
& =z_{m}^{1 /(1-\alpha)}[n_{m} \underbrace{\left(x^{\alpha}-x \delta(1-\Sigma)\right)}_{A>0}-\underbrace{x \delta \Sigma}_{B}\left(1-n_{g}\right)]+G
\end{aligned}
$$

In equilibrium, the first element of the expression above is $y_{m}-\delta k$ which is the consumption of the private production of $m$, therefore it is positive. This implies that $A>0$. Use again the fact that $n_{m}=1-n_{a}-n_{g}$ to obtain

$$
y_{m}-\delta k+y_{g}-\tau=z_{m}^{1 /(1-\alpha)}\left[\left(1-n_{g}\right)(A-B)-A n_{a}\right]+G .
$$

Again, consumption of the private production of $m$ is positive in equilibrium, thus $A-B>$ 0 . Therefore the right-hand side of (5) is an affine function of $n_{a}$ with a negative slope and a positive intercept. Turn to the left-hand side of (5):

$$
c_{m}=c_{a}\left(\frac{\omega}{1-\omega}\right)^{\varepsilon} p^{\varepsilon}=z_{a} \mathbf{k}_{a}^{\theta} n_{a}^{\mu+\theta}\left(\frac{\omega}{1-\omega}\right)^{\varepsilon} p^{\varepsilon}
$$

where the fact that $c_{a}=y_{a}$ in equilibrium. Substitute $p$ out

$$
\begin{aligned}
c_{m} & =z_{a} \mathbf{k}_{a}^{\theta} n_{a}^{\mu+\theta}\left(\frac{\omega}{1-\omega}\right)^{\varepsilon}\left(\frac{\alpha}{\theta}\right)^{\varepsilon}\left(\frac{z_{m}}{z_{a}}\right)^{\varepsilon} \mathbf{k}_{m}^{(\alpha-\theta) \varepsilon} \Sigma^{(1-\theta) \varepsilon} n_{a}^{(1-\theta-\mu) \varepsilon} \\
& =z_{a}\left(\frac{\omega}{1-\omega}\right)^{\varepsilon}\left(\frac{\alpha}{\theta}\right)^{\varepsilon}\left(\frac{z_{m}}{z_{a}}\right)^{\varepsilon} \mathbf{k}_{m}^{(\alpha-\theta) \varepsilon+\theta} \Sigma^{(1-\theta) \varepsilon+\theta} n_{a}^{(1-\theta-\mu) \varepsilon+\mu+\theta}
\end{aligned}
$$

Define

$$
C=\left(\frac{\omega}{1-\omega}\right)^{\varepsilon}\left(\frac{\alpha}{\theta}\right)^{\varepsilon} \Sigma^{(1-\theta) \varepsilon+\theta} x^{(\alpha-\theta) \varepsilon+\theta}
$$

then

$$
\begin{aligned}
c_{m} & =C z_{a}\left(\frac{z_{m}}{z_{a}}\right)^{\varepsilon}\left(z_{m}^{1 /(1-\alpha)}\right)^{(\alpha-\theta) \varepsilon+\theta} n_{a}^{(1-\theta-\mu) \varepsilon+\mu+\theta} \\
& =C z_{a}^{1-\varepsilon} z_{m}^{\varepsilon+((\alpha-\theta) \varepsilon+\theta) /(1-\alpha)} n_{a}^{(1-\theta-\mu) \varepsilon+\mu+\theta}
\end{aligned}
$$


Now (5) becomes

$$
C z_{a}^{1-\varepsilon} z_{m}^{\varepsilon+((\alpha-\theta) \varepsilon+\theta) /(1-\alpha)-1 /(1-\alpha)} n_{a}^{(1-\theta-\mu) \varepsilon+\mu+\theta}=\left(1-n_{g}\right)(A-B)-A n_{a}+\frac{G}{z_{m}^{1 /(1-\alpha)}}
$$

The coefficient on $z_{m}$ is

$$
\varepsilon+\frac{(\alpha-\theta) \varepsilon+\theta}{1-\alpha}-\frac{1}{1-\alpha}=(\varepsilon-1) \frac{1-\theta}{1-\alpha}
$$

so we have

$$
C z_{a}^{1-\varepsilon} z_{m}^{(\varepsilon-1) \frac{1-\theta}{1-\alpha}} n_{a}^{(1-\theta-\mu) \varepsilon+\mu+\theta}=\left(1-n_{g}\right)(A-B)-A n_{a}+\frac{G}{z_{m}^{1 /(1-\alpha)}}
$$

\section{References}

[1] Asian Development Bank (2003), "People's Republic of China: The Development of Private Enterprise," mimeographed.

[2] Brandt, L., Hsieh, C., and X. Zhu (2005), "China's Structural Transformation," mimeographed, University of California, Berkeley.

[3] Chow, G. (1993), "Capital Formation and Economic Growth in China," Quarterly Journal of Economics, pp. 809-842.

[4] Fan, S. and X. Zhang (2002), "Production and Productivity Growth in Chinese Agriculture: New National and Regional Measures," Economic Development and Cultural Change, pp. 819-838.

[5] Hayami, Y., and V. Ruttan (1985), Agricultural Development: An International Perspective, Baltimore, Maryland, Johns-Hopkins University Press.

[6] Hsueh, T. and Q. Li eds. (1999), China's National Income, 1952-1995, Boulder, Col.: Westview, 1999.

[7] Huang, J., Otsuka, K., and S. Rozelle (2004), "The Role of Agriculture in China's Development," mimeographed, UC-Davis.

[8] Jefferson, G., Rawski, T., and Y. Zheng (1989), "Growth Efficiency and Convergence in Chinese Industry: A Comparative Evaluation of the State and Collective Sectors," Department of Economics, University of Pittsburg Working Paper, 251.

[9] Jorgenson, D. and K. Nomura (2005), "The Industry Origins of Japanese Economic Growth," manuscript, Harvard University. 
[10] Li, K. W., (2003), "China's Capital and Productivity Measurement Using Financial Resources," Economic Growth Center Discussion Paper 851, Department of Economics, Yale University.

[11] Macrochina (2006), "Population Projections for China," Macrochina website.

[12] McMillan, J., Whalley, J., and L. Zhu (1989), "The Impact of Chinese Economic Reforms on Agricultural Productivity Growth," Journal of Political Economy, pp. 781-807.

[13] Naughton, B., (2005), "Township and Village Enterprises," mimeographed, University of California, San Diego.

[14] Manchester Guardian (2005), "China to Overtake Britain after Beijing Understates Growth," December 14.

[15] OECD (2005), Economic Surveys: China, Paris: OECD Publishing, September.

[16] People's Republic of China, National Bureau of Statistics of China (1988), 1987 Tabulations of China 1 percent Population Census of China (Zhongguo 1987 nian 1 \% renkou chouyang diaocha zilao). Beijing: China Statistical Publishing House.

[17] People's Republic of "China, State Council and National Bureau of Statistics of China (2002), Tabulation on the 2000 Population Census of the People's Republic of China (Zhongguo 2000 nian renkou pucha zilioa). Beijing: China Statistical Publishing House.

[18] People's Republic of China, National Bureau of Statistics of China (various annual issues from 1981), China Statistical Yearbook (Zhongguo tongli nianjian). Beijing: China Statistical Publishing House.

[19] Provincial Statistical Yearbooks (1997-2004) (tongli nianjian) for 25 provinces.

[20] Rawski, T., (2004), "China's Growth Prospects," mimeographed, University of Pittsburg.

[21] Research Institute of Economy, Trade, and Industry (RIETI) (2004), "The Huge Debate over Privatization and Management Buyouts-Can the Drain on State-owned Assets Be Justified?", mimeographed, July.

[22] Young, A., (2003), "Gold into Base Metal: Productivity Growth in the People's Republic of China During Reform," Journal of Political Economy, pp. 1220-1261.

[23] Zhang, L., J. Huang, and S. Rozelle, (2002), "Employment, Emerging Labor Markets, and the Role of Education in Rural China," China Economic Review, pp. 313-328. 
Employment Shares of Agriculture, Public, and Private Industrial Sectors

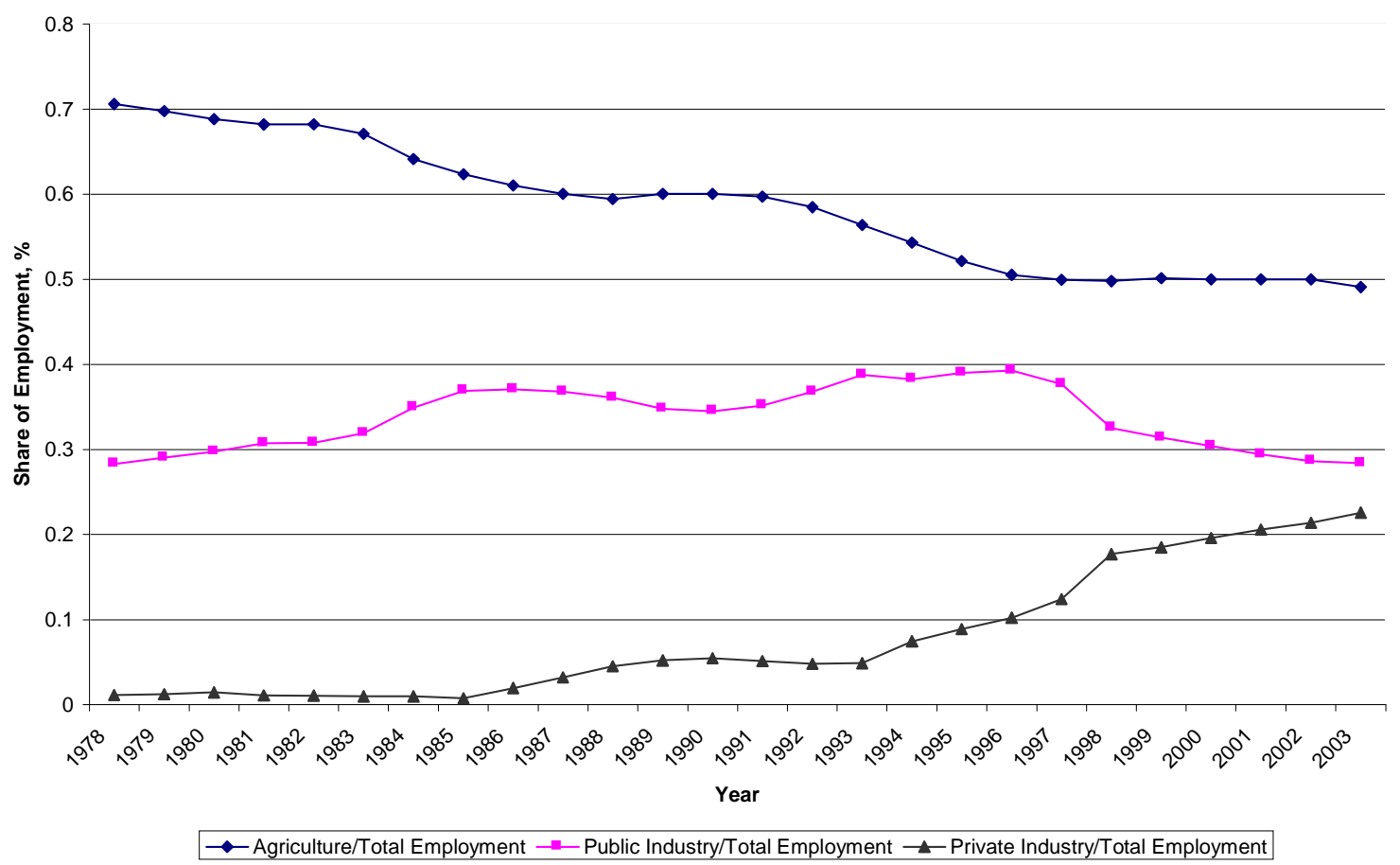

Figure 1: Employment Shares, 1978-2003. 
Agriculture-Industry Price Ratio

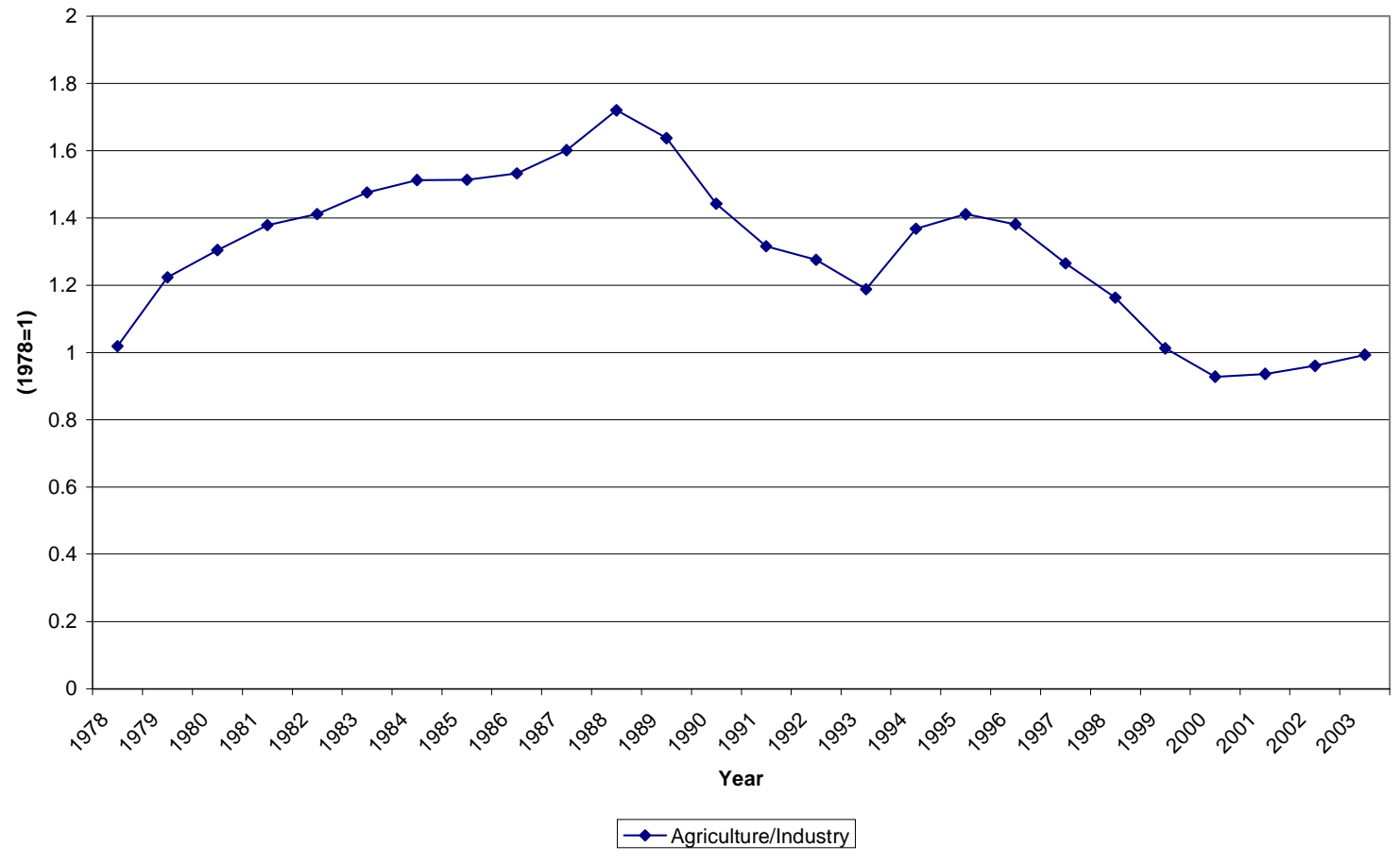

Figure 2: Prices of Agricultural Goods Relative to Industrial Goods. 


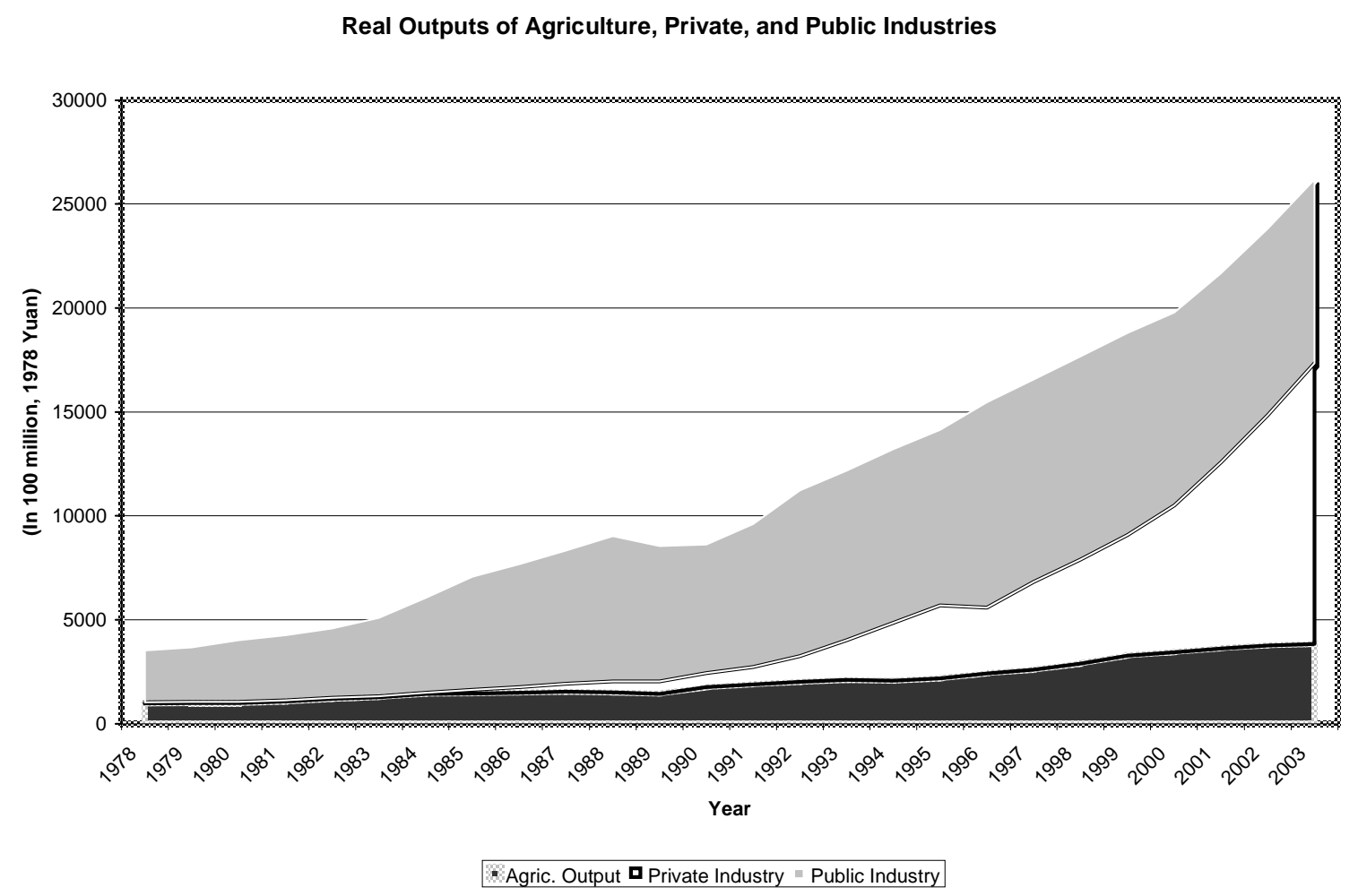

Figure 3: Real Outputs of Agriculture, Private and Public Industries, 1978-2003. 
Real Output/Labor in Agriculture, Public, and Private Industries

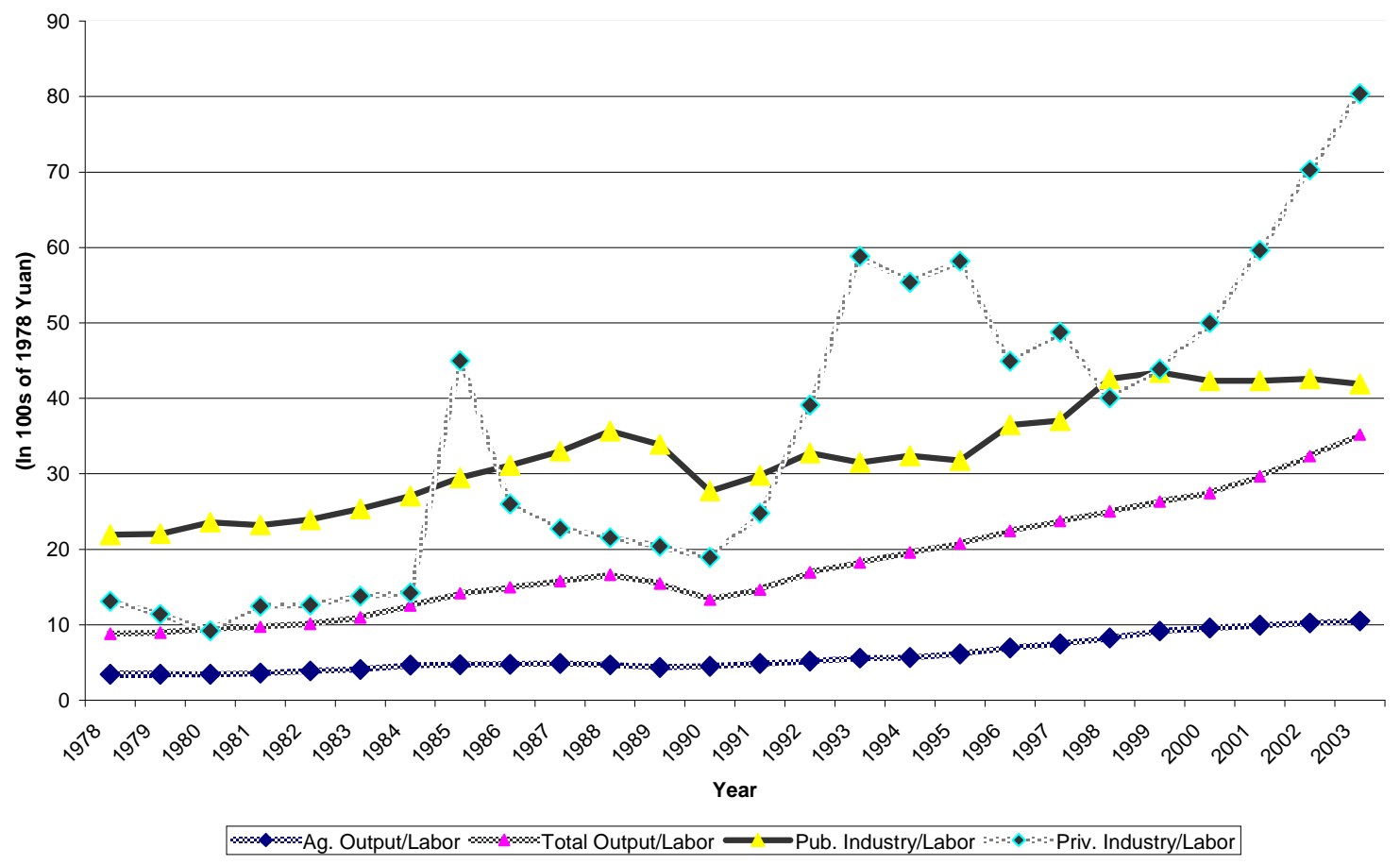

Figure 4: Real Output per Worker Ratios (Labor Productivity) by Sector, 1978-2003. 


\section{Capital Output Ratios}

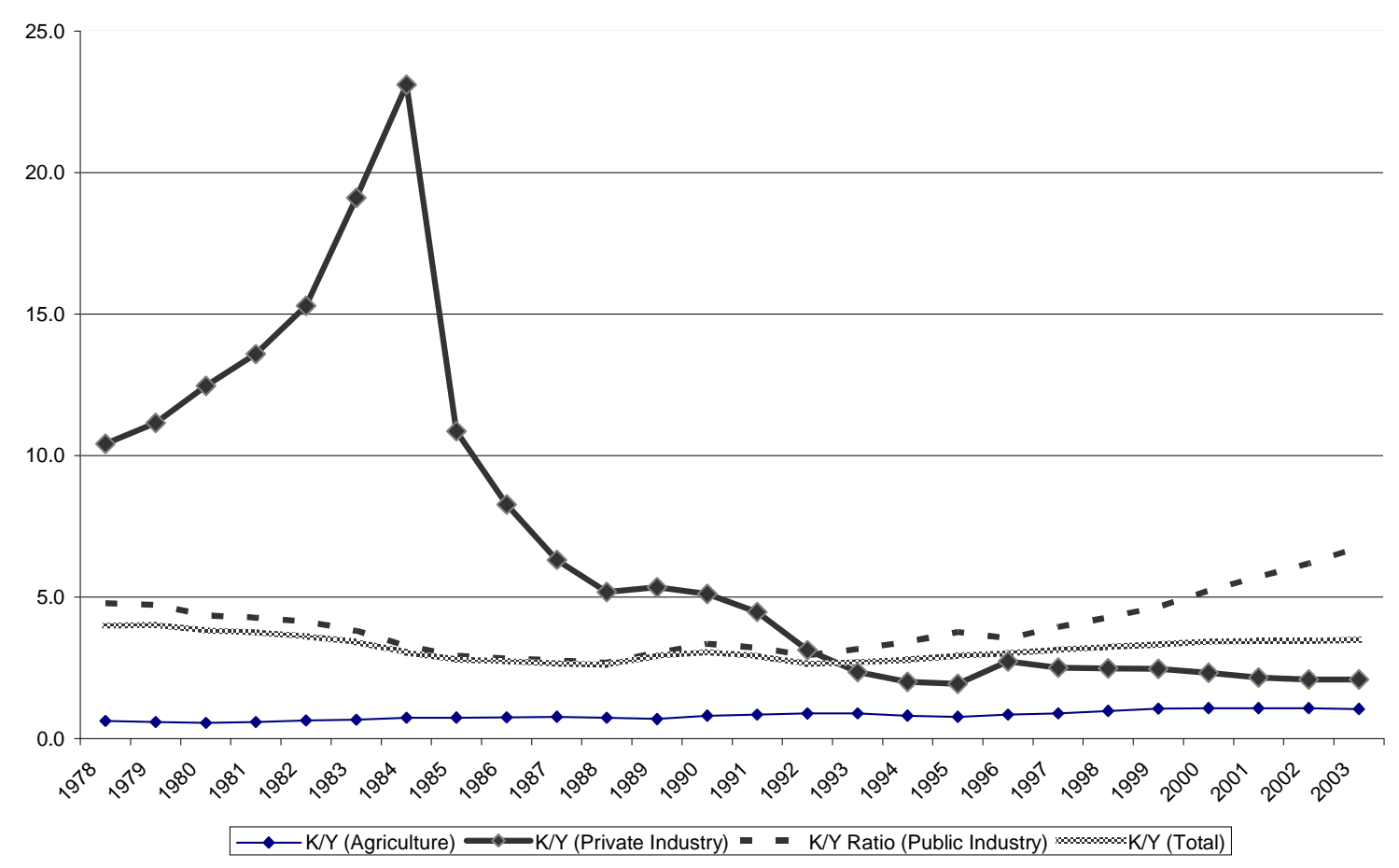

Figure 5: Capital-Output Ratios for the Economy, and by Sectors, 1978-2003. 
Investment Shares of Agriculture, Public, and Private Industrial Sectors

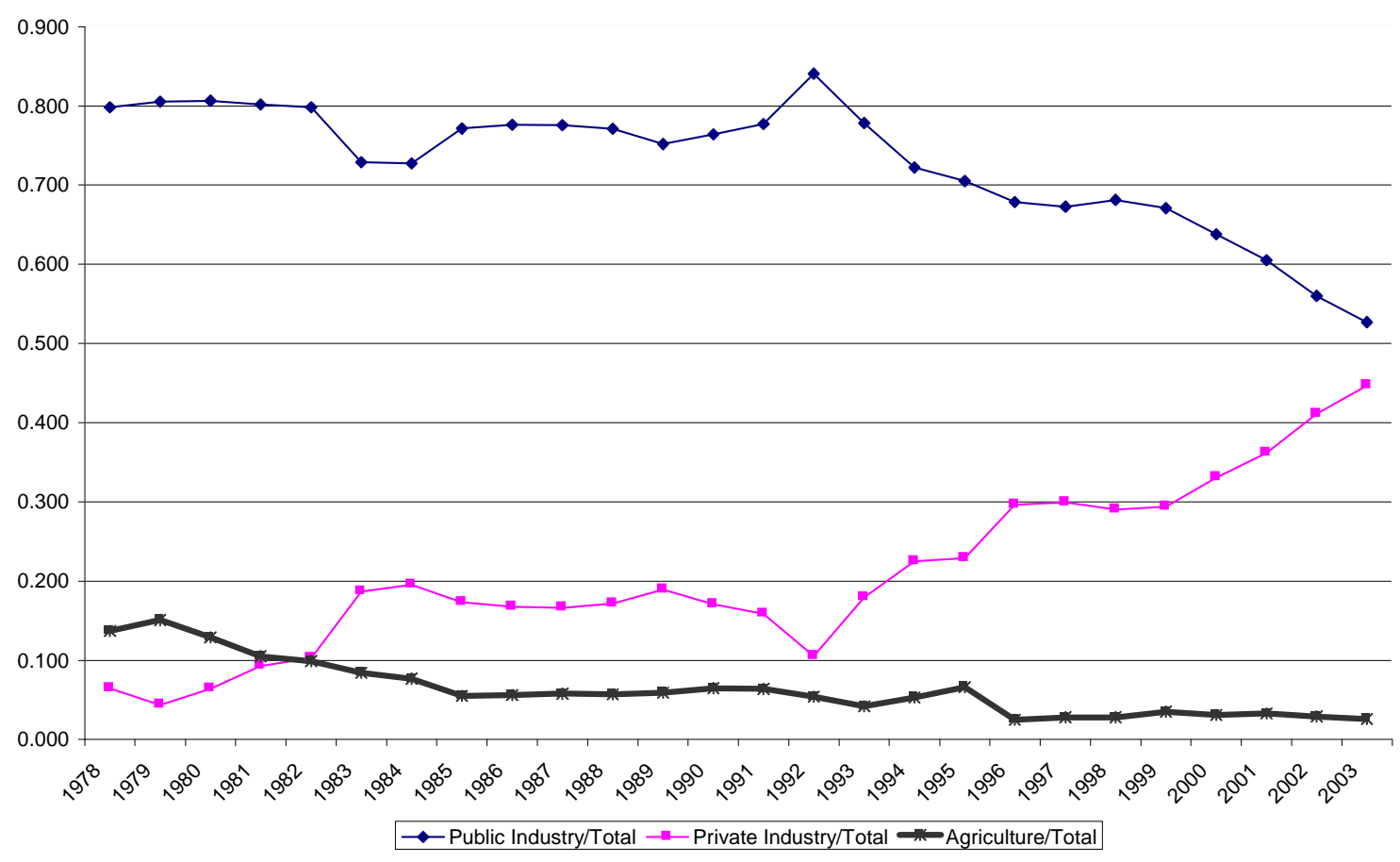

Figure 6: Investment Shares, 1978-2003.

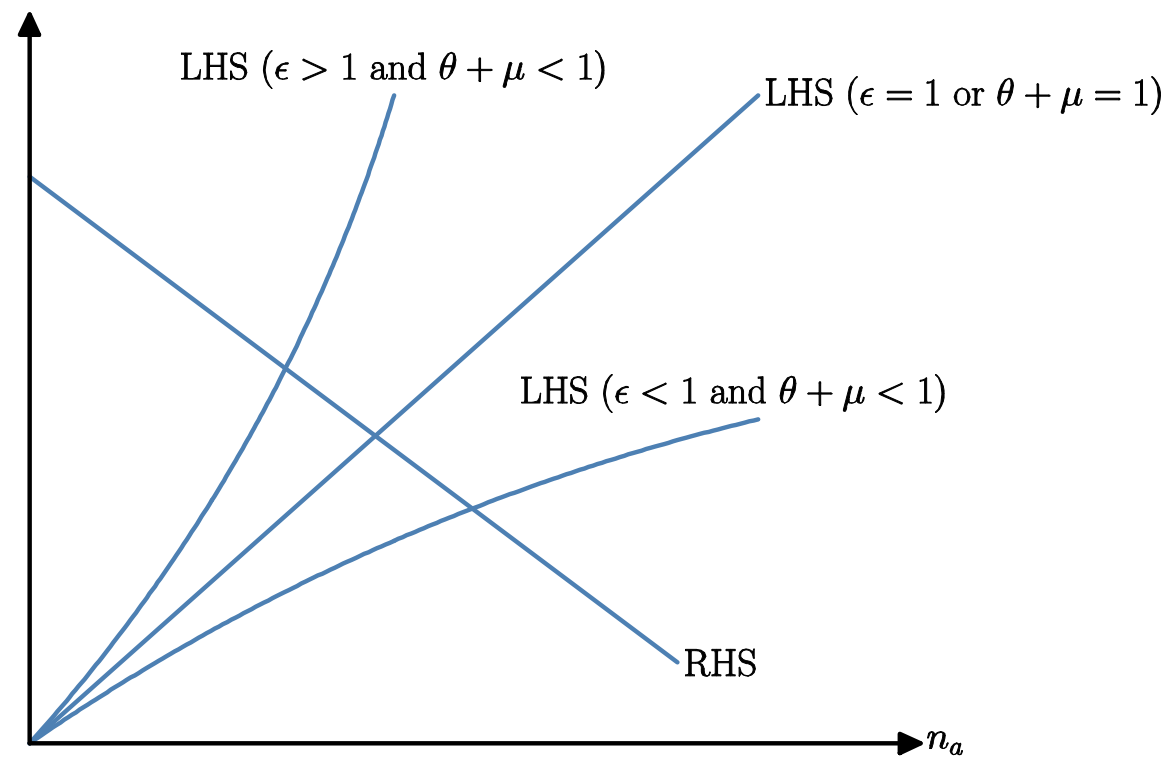

Figure 7: The Determination of $n_{a}$. 


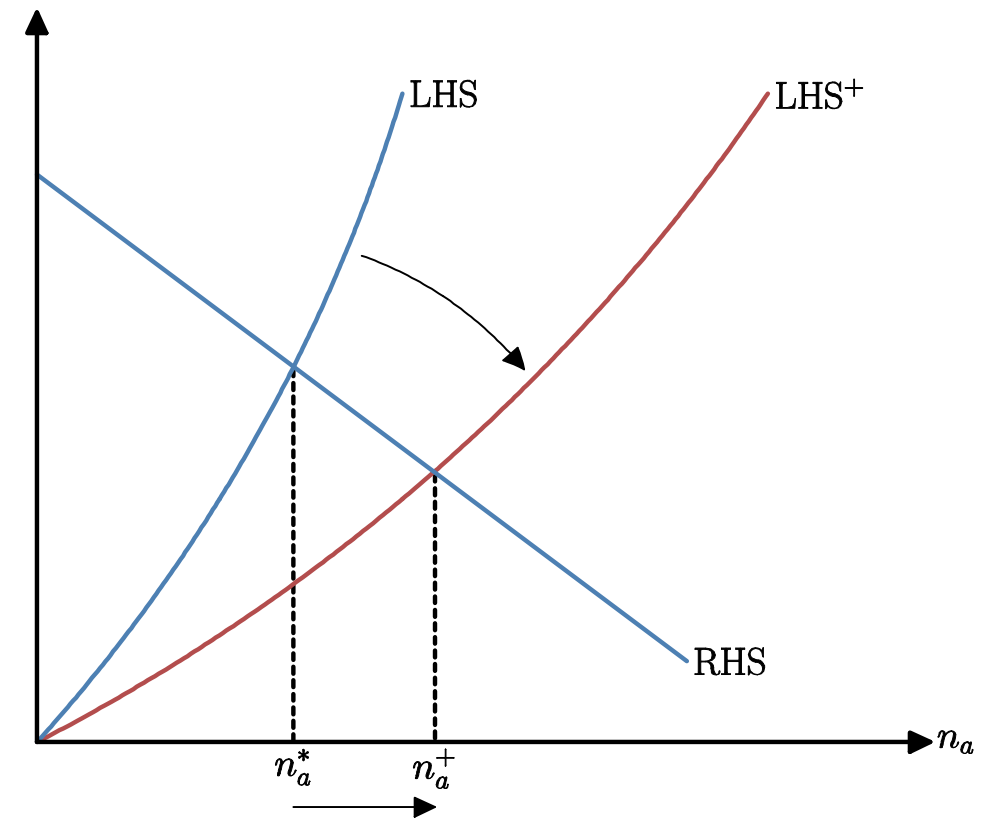

Figure 8: Effect of an Increase in Agricultural Total Factor Productivity when Goods are Substitutes.

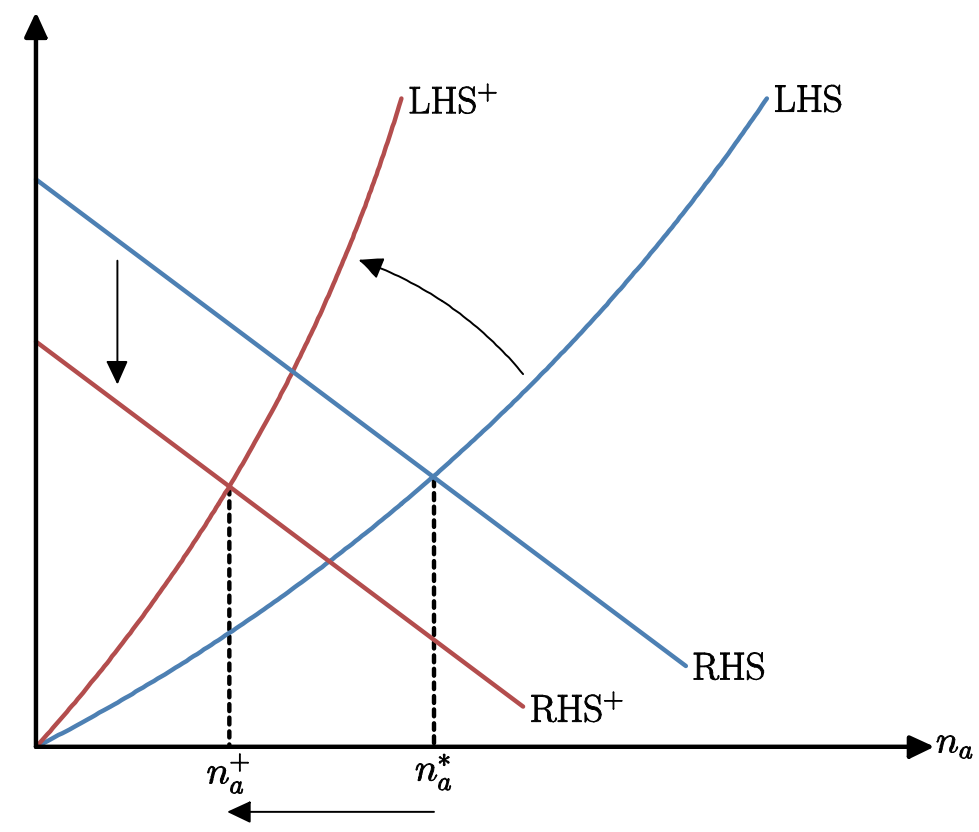

Figure 9: Effect of an Increase in Nonagricultural Total Factor Productivity when Goods are Substitutes. 


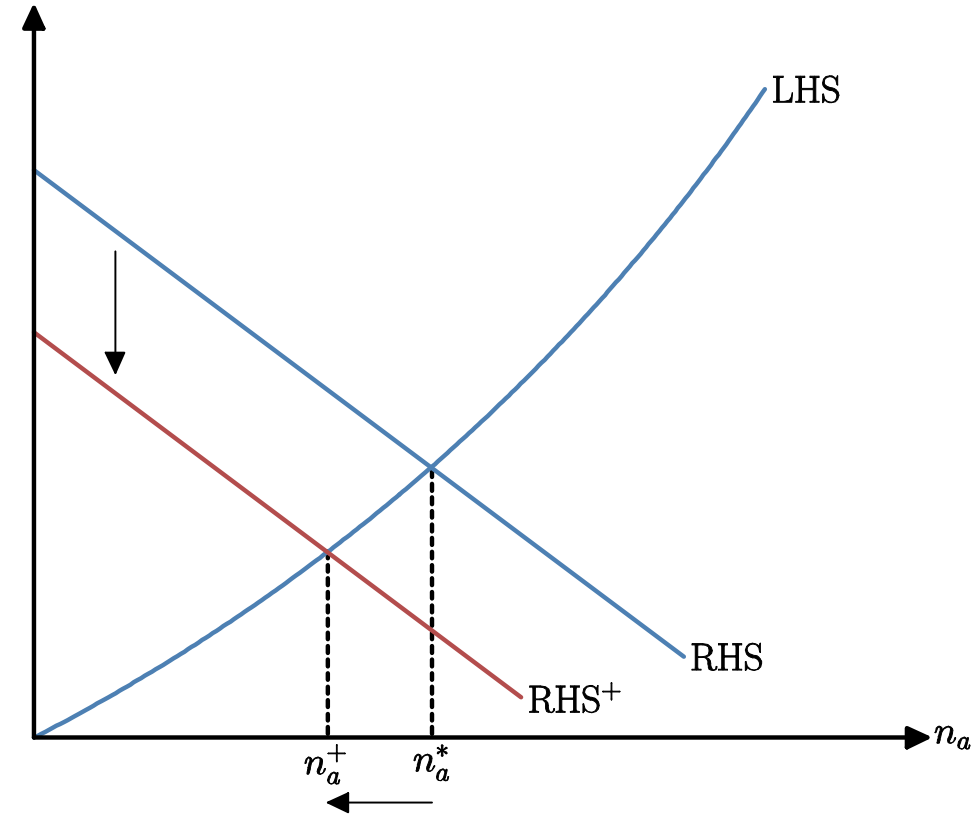

Figure 10: Effect of an Increase in the Public Production of the Nonagricultural Good.

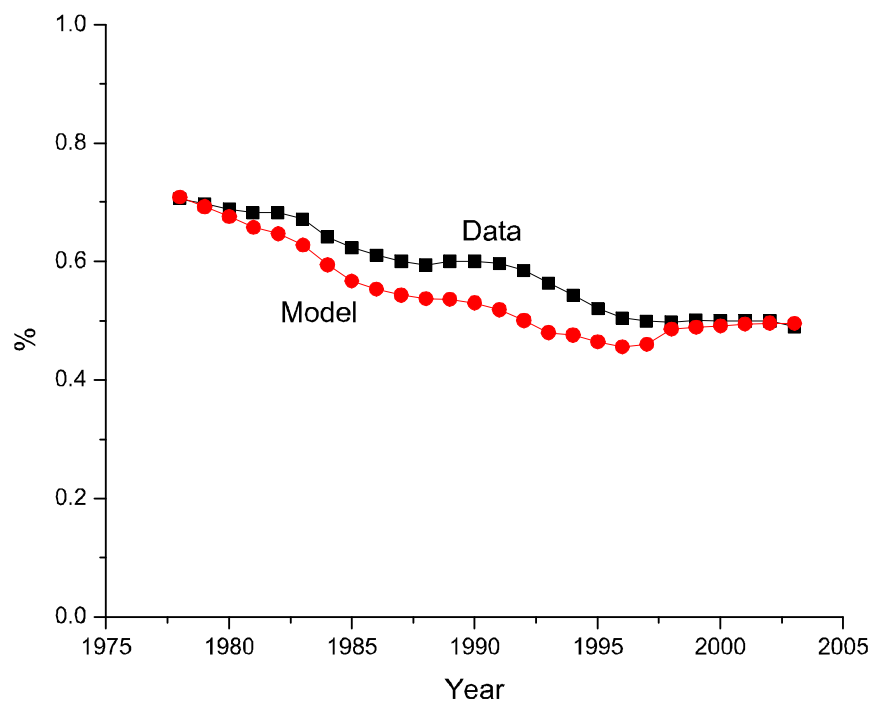

Figure 11: Employment Share of Agriculture, Chinese Data and Model, 1978-2003. 


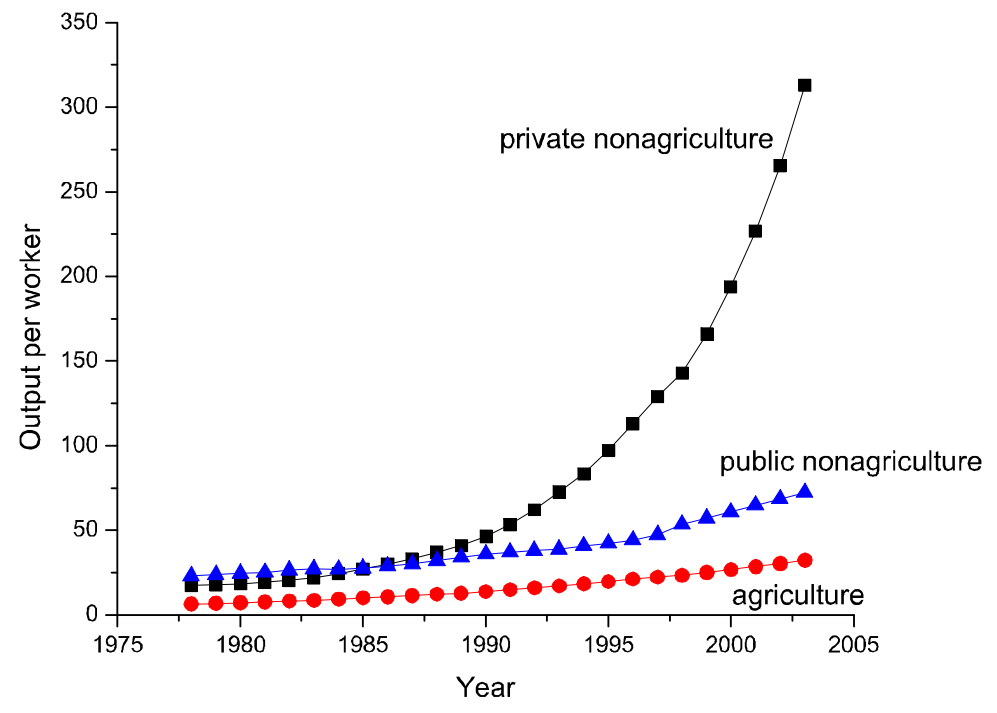

Figure 12: Simulated Output per Worker.

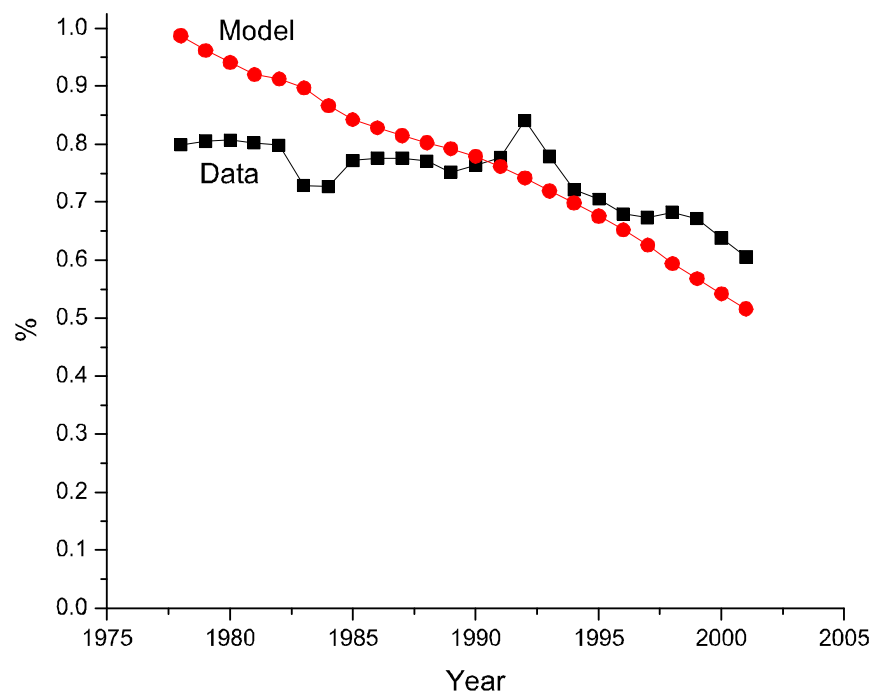

Figure 13: Share of Public Investment in Total Investment, Chinese Data and Model, 1978-2002. 


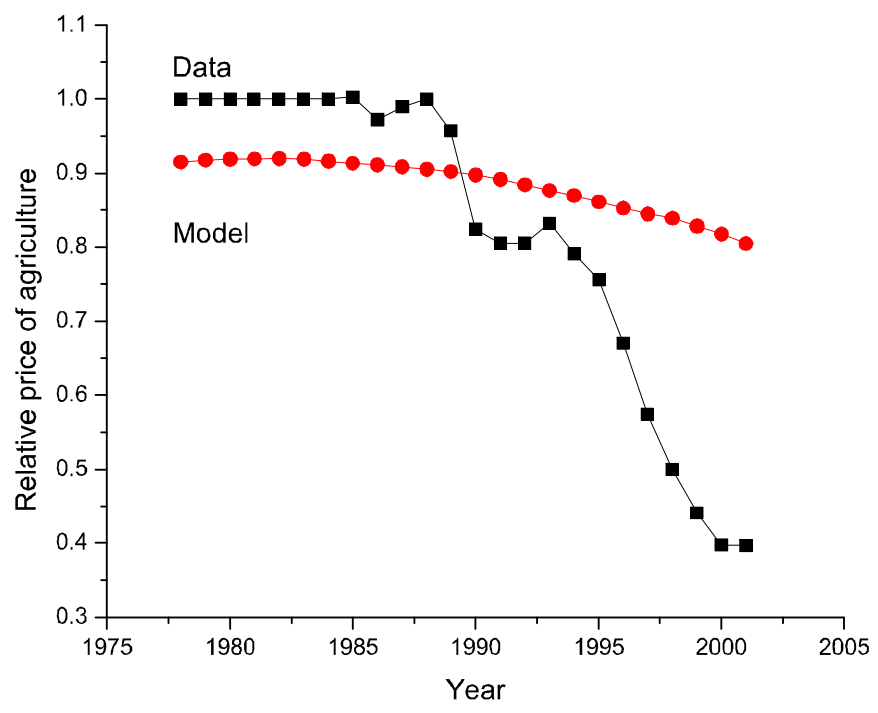

Figure 14: Relative Price of Agriculture, Chinese Data and Model, 1978-2003. 